\title{
Feeding habits and niche separation among the deep-sea chimaeroid fishes Harriotta raleighana, Hydrolagus bemisi and Hydrolagus novaezealandiae
}

\author{
Matthew R. Dunn*, Lynda Griggs, Jeff Forman, Peter Horn \\ National Institute of Water and Atmospheric Research Ltd., 301 Evans Bay Parade, Greta Point, Wellington, New Zealand
}

\begin{abstract}
The diets of Harriotta raleighana, Hydrolagus bemisi and Hydrolagus novaezealandiae were determined from examination of digestive tract contents from specimens sampled at depths of 219 to $876 \mathrm{~m}$ on the submarine ridge, Chatham Rise, New Zealand. All 3 species fed predominantly on benthic epifauna and infauna. Similarity percentages indicated the diet of $H$. raleighana was characterised by polychaetes and molluscs, $H$. bemisi by crabs and polychaetes, and $H$. novaezealandiae by crabs and sea urchins. Multivariate analyses using distance-based linear models found the most important predictors of diet variability were a categorical predictor for the subtropical front (STF) and bottom temperature. Cluster analysis of species subgroups indicated there was a greater similarity in diet between $H$. raleighana and $H$. bemisi, and between $H$. bemisi and $H$. novaezealandiae, in similar locations, than between subgroups of $H$. bemisi in different locations. Generalised additive models indicated that depth was the most important spatial predictor of research trawl survey catch rates, and depth separation was most pronounced between $H$. raleighana and $H$. novaezealandiae. Other significant predictors of diet variability included longitude, and fish length or weight. In all 3 species the diet of smaller fish included more polychaetes, small crustaceans and gastropods, and the diet of larger fish contained more decapod crustaceans. The primary factor determining niche separation among the 3 species appears to be depth and distribution rather than dietary specialisation.
\end{abstract}

KEY WORDS: Diet · Distribution · Deep-sea fish $\cdot$ Ghost shark $\cdot$ Spookfish $\cdot$ New Zealand

\section{INTRODUCTION}

There is a growing recognition that fisheries management policy needs to acknowledge, understand and quantify the interactions between the different components within marine ecosystems (Cury et al. 2005). Predation and competition are important to fish population dynamics (Bax 1998), and the study of fish trophic interactions is therefore a key component in the move towards an ecosystem approach to fisheries management (Francis et al. 2007).

This study investigates the diet and trophic interactions of 3 deep-sea chimaeroid fishes, Harriotta raleighana Goode \& Bean, 1895, Hydrolagus bemisi Didier, 2002 and Hydrolagus novaezealandiae Fowler,
1910, on the submarine ridge, Chatham Rise, New Zealand. The chimaeras (Chondrichthyes: Holocephali) are believed to have evolved from an ancient shark group, with 3 extant families containing about 45 species worldwide, most of which are found in deep water ( $>200 \mathrm{~m}$ depth) on the continental slope (Last \& Stevens 2009). The morphology of chimaeras differs from true sharks and rays in several ways, including chimaeras having an upper jaw fused to the skull, teeth fused into beak-like plates and a digestive tract lacking a stomach (Last \& Stevens 2009).

Chimaeras are of particular interest because they are a bycatch in commercial fisheries, yet their biology and ecology are virtually unknown. Harriotta raleighana is an infrequent bycatch in some deep-sea trawl fisheries 
(Francis 1998, Anderson 2009), but Hydrolagus bemisi and Hydrolagus novaezealandiae are a common bycatch, and as a result they were introduced into the New Zealand quota management system in 1998 ( $H$. novaezealandiae) and 1999 ( $H$. bemisi) (Ministry of Fisheries 2009). New Zealand catches of both Hydrolagus species have historically been uncertain and under-reported (Francis 1998), and are usually below the total allowable commercial catch (TACC) limits: in the fishing year 2007-2008 the total catches were $818 \mathrm{t}$ (TACC of $1780 \mathrm{t}$ ) of $H$. bemisi, and $1911 \mathrm{t}$ (TACC of $3012 \mathrm{t}$ ) of $H$. novaezealandise (Ministry of Fisheries 2009). Because of the paucity of information on chimaeras, it is unknown whether the catches of Hydrolagus are sustainable, or whether the TACCs are appropriate (Ministry of Fisheries 2009).

Harriotta raleighana is commonly known as the longnose chimaera, bigspine spookfish or narrownose chimaera and has been reported at depths of 350 to $2600 \mathrm{~m}$ in the Atlantic, Pacific and Indian oceans (Last \& Stevens 2009). The diet of $H$. raleighana is poorly known: in the north Atlantic Ocean, Sedberry \& Musick (1978) examined the digestive tracts of 3 specimens and found primarily small gastropods and amphipods. Mauchline \& Gordon (1983) examined 8 specimens of $H$. raleighana and found primarily polychaetes and amphipods, with some squid, anemones, isopods and pagurids present, and González et al. (2007) examined 57 specimens and found primarily polychaetes, bivalves, and gastropods, with a variety of other small crustaceans, molluscs, echinoderms, jellyfish, sponges and fish remains.

Hydrolagus bemisi is commonly known as the pale ghost shark and, although only recently formally described, has been recognised for many years. $H$. bemisi has been reported from waters of 270 to $1200 \mathrm{~m}$ depth around New Zealand (Horn 1997), where it is most abundant at depths of 400 to $1000 \mathrm{~m}$ and is a characteristic species in deep water demersal fish assemblages (Horn 1997, Bull et al. 2001, Francis et al. 2002). The diet of $H$. bemisi is known only qualitatively and includes small crabs and salps, along with some other crustaceans, molluscs, sea urchins, starfish, polychaetes and squid (Horn 1997).

Hydrolagus novaezealandiae is commonly known as the dark ghost shark and is believed to be endemic to the waters around New Zealand, where it occurs at depths of 30 to $850 \mathrm{~m}$, and is most abundant at depths of 150 to $500 \mathrm{~m}$ (Horn 1997). The juveniles of $H$. novaezealandiae are believed to be more abundant in waters shallower than $200 \mathrm{~m}$ (Horn 1997). The diet of $H$. novaezealandiae is known only qualitatively, and includes benthic crustaceans, particularly Munida spp. and small crabs, with some prawns, starfish, fish, salps, polychaetes and molluscs (Horn 1997).

Chatham Rise is a submarine ridge that runs eastwards for about $1000 \mathrm{~km}$ from the east coast of the South Island of New Zealand, rising up from depths of about $3000 \mathrm{~m}$ to $50 \mathrm{~m}$ at the western end, and to sea level at the eastern end (Fig. 1). The subtropical front (STF) is a permanent feature where warmer subtropical surface water from the north meets colder subantarctic surface water from the south (Heath 1985, Uddstrom \& Oien 1999). The mixing associated with the STF extends over a wide latitudinal range $(\sim 100 \mathrm{~km})$, but the strongest surface temperature gradients, which are found towards the south of the frontal zone, occur on the southern flank of Chatham

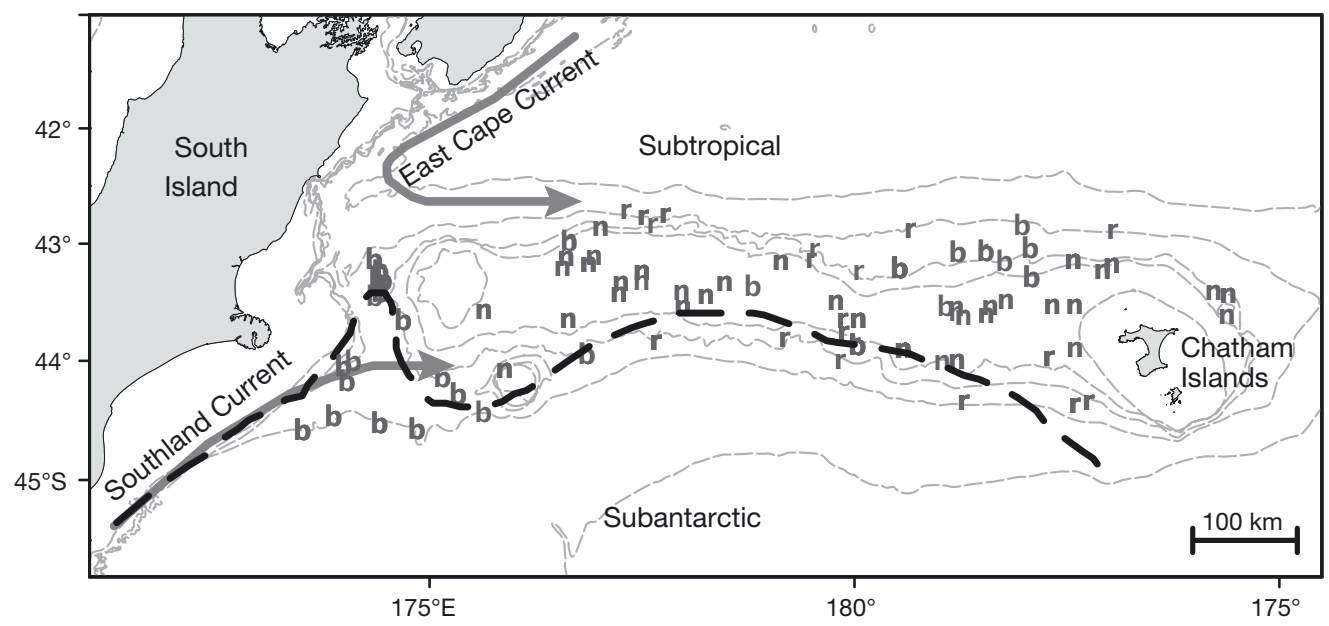

Fig. 1. General position of the subtropical front at the sea surface (broken bold line, from Uddstrom \& Oien 1999) and associated water masses (subtropical and subantarctic), predominant surface currents, and the 200, 350, 500, 800 and $2000 \mathrm{~m}$ isobaths (dashed grey lines), over the Chatham Rise. The grey text symbols indicate stomach sample sites for Harriotta raleighana (r), Hydrolagus bemisi (b) and H. novaezealandiae (n) 
Rise west of about $177^{\circ} \mathrm{W}$, tending northwards between 177 and $180^{\circ} \mathrm{W}$, then becoming more diffuse and tending southwards past the Chatham Islands (Uddstrom \& Oien 1999, Sutton 2001; Fig. 1). Pronounced temperature gradients exist from the surface to the seabed, and to depths of at least $900 \mathrm{~m}$ (Sutton 2001, Dunn et al. 2009). The STF is a region of heightened primary productivity (Murphy et al. 2001), supporting an abundant mesopelagic biomass, particularly on the west side of the rise (McClatchie \& Dunford 2003). Chatham Rise and the STF act as an area of pelagic (Robertson et al. 1978, Bradford-Grieve et al. 1999), demersal (Bull et al. 2001, Leathwick et al. 2006) and benthic (Probert et al. 1996, McKnight \& Probert 1997, Nodder et al. 2003) ecosystem discontinuity. The pronounced ecosystem changes across the STF are likely to influence both the distribution and diet of chimaeras through variations in environmental conditions and prey availability. In this study we examine species distribution and variability in diet in relation to a range of environmental factors.

This study provides the first detailed analysis of the diets and distributions of Harriotta raleighana, Hydrolagus bemisi and Hydrolagus novaezealandiae, clarifying the ecological role of chimaeras and providing insight into the possible role of competition in determining the realized niche of chimaeras (Pulliam 2000).

\section{MATERIALS AND METHODS}

Diet sampling. Biological samples of Hydrolagus bemisi and $H$. novaezealandiae were obtained from stratified random research bottom trawl surveys on the Chatham Rise during December 2004 to January 2005, December 2005 to January 2006 and December 2006 to January 2007 (Stevens et al. 2009). Biological samples of Harriotta raleighana were collected only during the 2005 to 2006 survey. The survey area consisted of 26 strata defined by location and depth covering $146855 \mathrm{~km}^{2}$ and depths between 200 and $1000 \mathrm{~m}$. The trawl employed was a full-wing bottom trawl, which had a headline height of about $7 \mathrm{~m}$, a door spread of about $115 \mathrm{~m}, 100 \mathrm{~m}$ sweeps, a cod-end mesh of $60 \mathrm{~mm}$, and a ground rope fitted with $500 \mathrm{~mm}$ steel bobbins. The net was towed by the RV 'Tangaroa' at each station for about 3 nautical miles (n miles), at a speed of 3.5 knots (n miles $\mathrm{h}^{-1}$ ), during daylight hours, at about 100 stations per survey.

Sampled fish were measured for length (dorsal fin length, DF), as determined to the nearest $1 \mathrm{~mm}$ from the tip of the snout to the posterior dorsal end of the second dorsal fin in Harriotta raleighana or dorsal caudal fin in Hydrolagus bemisi and $H$. novaezealandiae. Sex was also determined and fish were weighed to the nearest $5 \mathrm{~g}$. Fish with obviously regurgitated or everted digestive tracts were not sampled. At sea, digestive tracts were sealed by fixing cable ties around the oesophagus and posterior gut, then the oesophagus was cut in front of the tie and the intestines below the tie, and the intestinal tract was removed, labelled, frozen at $-20^{\circ} \mathrm{C}$ and returned to the laboratory. In the laboratory, each intestinal tract was thawed and the contents removed and rinsed with water through a $500 \mu \mathrm{m}$ mesh steel sieve to remove fluid and very fine material. Recognisable prey items were then identified to the lowest possible taxonomic level under a stereo microscope, with the use of reference guides and a reference collection of preserved specimens and hard parts (fish otoliths and cephalopod beaks) held at the National Institute of Water and Atmospheric Research (NIWA), Wellington. For each prey category, the number of prey individuals was estimated, and the wet weight was recorded to the nearest $0.01 \mathrm{~g}$ after surface water was removed with blotting paper. A fragmented prey count was based on the number of eyes, heads, mouth parts, tails or telsons, paired otoliths or other anatomical parts traceable to a single specimen.

Diet analyses. To complete analyses of diet variability the prey items were aggregated into taxonomic categories. The unidentifiable prey (including unidentifiable Annelida, Crustacea, Mollusca and shell fragments presumably from Mollusca) as well as parasites found in the digestive tracts were excluded from detailed analyses.

To assess the adequacy of the samples for the analyses of diet variability, the cumulative diversity of the categorised digestive tract contents measured with the Brillouin index of diversity $(H B)$ was plotted against the cumulative number of non-empty digestive tracts (Alonso et al. 2002). The mean and $95 \%$ CI were calculated from 1000 curves based upon different random orders of the digestive tracts. The sample was considered adequate if the mean sample diversity $(H B)$ was more than $95 \%$ of the asymptotic diversity $\left(H B_{\mathrm{A}}\right)$, estimated from a fitted curve of the form: $H B=a N /(1+$ $b N)$, where $a$ and $b$ are constants, $N$ is the number of digestive tracts sampled, and the asymptote is given by $a / b$ (Dunn 2009).

The contribution of different prey items to the diet was determined by the numerical importance $(\% N)$, frequency of occurrence $(\% F)$, and mass ( $\% W$ ) (Hyslop 1980). The index of relative importance (IRI), which incorporates the previous 3 indices, was calculated as IRI $=\% F(\% N+\% W)$, and expressed as a percentage (\%IRI) (Cortés 1997), providing an optimal balance of the 3 indices (Liao et al. 2001). Bootstrap methods, consisting of 1000 replicates of random samples with replacement of digestive tracts from the original data set (i.e. both empty and non-empty digestive tracts) 
stratified by survey and tow, were used to estimate confidence intervals (2.5th and 97.5th percentiles) around the dietary statistics ( $\% N, \% F, \% W$ and $\%$ IRI). This 2-stage bootstrap method provides more realistic estimates of the uncertainty associated with these indices (Tirasin \& Jørgensen 1999).

Distance-based linear model (DistLM) analysis was used to identify which of the potential predictors explained most of the variability in diet (Anderson et al. 2008). The diet was analysed by using prey weight. The data were first standardised, by expressing the weight of each prey item as a proportion of the total weight in each digestive tract, thereby assuming that weight was a more accurate descriptor of the diet than occurrence or prey frequency, and each digestive tract was an equally good descriptor of overall diet. The data were then square-root transformed, which has been considered the most appropriate transformation for proportion data (Platell \& Potter 2001). A dissimilarity matrix was subsequently calculated using Bray-Curtis distances (Bray \& Curtis 1957). The potential predictors were total fish weight, the survey, latitude, longitude, the surface temperature and bottom temperatures, time of day, depth of tow (mean of the tow start and finish depths) and 2 categorical location predictors, i.e. west-east and the STF. The west-east predictor consisted of east and west strata, split at the $180^{\circ}$ longitude, and was based upon observations of increasing primary productivity and much higher mesopelagic biomass on the western rise (Murphy et al. 2001, McClatchie \& Dunford 2003). The categories in the STF predictor were bank (200 to $349 \mathrm{~m}$ ), crest (350 to $499 \mathrm{~m}$ ), northern slope (500 to $800 \mathrm{~m}$ ) and southern slope (500 to $800 \mathrm{~m})$. The boundaries of these strata were derived from studies of oceanography (Uddstrom \& Oien 1999), mesopelagic communities (Robertson et al. 1978, Bradford-Grieve et al. 1999), including the vertical extent of mesopelagic layers (McClatchie \& Dunford 2003), demersal fish assemblages (Bull et al. 2001) and invertebrate communities (Probert et al. 1996, McKnight \& Probert 1997, Nodder et al. 2003). Significant and relevant correlations between predictors varied between species samples and are reported in the results. The most significant predictors were selected by means of the 'best' selection method, which used both the Akaike's information criterion (AIC) and Bayesian information criterion (BIC) (Kuha 2004). The most parsimonious model was selected by plotting the top 50 models chosen using each criterion as a scatter plot and selecting the models that appeared in both criteria and had the lowest combined criterion scores (Anderson et al. 2008). The results of the DistLM analysis were a marginal test that fitted each predictor individually and a conditional test that fitted each predictor conditional on the predictor(s) already in the model (Anderson et al. 2008).

To further investigate the effects of the predictors identified from the DistLM analysis, the continuous predictors were first binned. The bin limits were chosen so that the number of observations in each bin was approximately equal. This was considered objective given that there were no a priori known biologically meaningful boundaries for these predictors. The target number of samples in each bin was estimated to be sufficiently large to describe $>85 \%$ of the diversity of the overall diet, which avoided any bins containing small, and thus potentially biased, samples. The binned data were averaged (mean of standardised proportions of prey species), square-root transformed and then analysed with SIMPER (similarity percentages), using PRIMER v. 6 (Clarke \& Warwick 2006). The SIMPER was used to describe, based on the contribution to the overall Bray-Curtis dissimilarity, which prey species were characteristic of the diet within each group.

Dietary overlap was estimated by means of hierarchical agglomerative clustering (Clarke \& Gorley 2006). Dietary overlap was first analysed at the species level, and then by using intraspecific groups, to see whether intraspecific similarities were greater than interspecific similarities. To avoid any intraspecific groups containing small and, thus, potentially biased samples, the groups were determined by using only the most important predictor of diet variability in each species. The data were standardised by averaging percent prey weight within predator groups, followed by square-root transformation. A dissimilarity matrix was calculated using Bray-Curtis distances, and a cluster analysis was performed with the average linkage method (Jaksic \& Medel 1990).

Distribution analyses. Standardised tow-by-tow catch rates $\left(\mathrm{kg} \mathrm{km}^{-2}\right)$ of Harriotta raleighana, Hydrolagus bemisi and $H$. novaezealandiae were obtained from stratified random research bottom trawl surveys, covering all but the far southeast corner of Chatham Rise, annually between December 1993 to January 1994 and December 2006 to January 2007 (Stevens et al. 2009). Bull et al. (2001) analysed a similar data set (surveys from 1991-1992 to 1998-1999) and found demersal fish abundances and assemblages were best described by depth, latitude and longitude. The effect of these predictors on chimaera abundance was modelled with generalised additive model regressions (GAMs) (Hastie \& Tibshirani 1990). The predictand was $\log$ (catch rate), with the GAM having a gaussian distribution and identify link function. A small amount was added to the catch rate $(0.001 \mathrm{~kg})$, to reduce the potential bias caused by otherwise excluding zero catches, particularly towards the edge of the species range. The predictors were fitted using a stepwise approach ('both 
directions') with the AIC. The models were fitted by means of the stepAIC and gam functions in R (www.Rproject.org). To investigate ontogenetic shifts in depth distribution within each species, the relationship between median fish length and depth in each tow was plotted and described by linear regression.

\section{RESULTS}

\section{Harriotta raleighana}

Of 100 specimens of Harriotta releighana examined, 5 had their digestive tracts empty of prey. The analyses of digestive tract contents led to the identification of 2051 individual prey in 41 prey groups, with a total weight of $162 \mathrm{~g}$ (Table 1). The number of prey items per digestive tract varied between 1 and 69, with $50.0 \%$ of digestive tracts containing 15 or fewer prey items, and $2.0 \%$ containing only a single prey item. Most digestive tracts $(73.6 \%)$ were one-quarter to three-quarters full; none were classified as full. One digestive tract contained only well-digested or unidentifiable remains of prey, which left 94 for detailed analyses of diet. These specimens were sampled at depths between 397 and $876 \mathrm{~m}$, had a median DF length of $71.6 \mathrm{~cm}$ (range, 29.2 to $91.7 \mathrm{~cm}$ ), and a length $(\mathrm{cm})$ to weight $(W$, in $\mathrm{g})$ relationship of $W=0.0032 \times$ $\mathrm{DF}^{2.997}\left(\mathrm{r}^{2}=0.94\right)$. The diversity of prey categories reached $95 \%$ of the estimated asymptote after 27 digestive tracts were examined (Fig. 2a), indicating that the sample was large enough to describe the diversity of the diet when using the assumed prey categorisation.

The diet of Harriotta raleighana was characterised by polychaetes and molluscs (Table 1). Polychaetes occurred in $83.0 \%$ of the digestive tracts and contributed $36.7 \%$ of the prey weight, with the relatively large Aphroditidae being the most frequently identified species. Mollusca were also frequently identified and included slightly more gastropods than bivalves $(13.7 \%$ and $11.1 \%$ by weight, respectively). The gastropod prey included the sea slug Philine sp., and also gastropod eggs. The importance of molluscs in the diet was reflected in the large weight of shell fragments measured. Although Brachyura were less frequent prey than gastropods, they were more important in terms of prey weight. Anomura, largely Munida gracilis, occurred frequently in the digestive tracts and accounted for $9.9 \%$ of the prey weight. Isopods were also frequently identified, but accounted for little prey weight.

The DistLM analysis indicated significant relationships between Harriotta raleighana diet and several of the predictors, with the most parsimonious model having the predictors STF, fish length and longitude
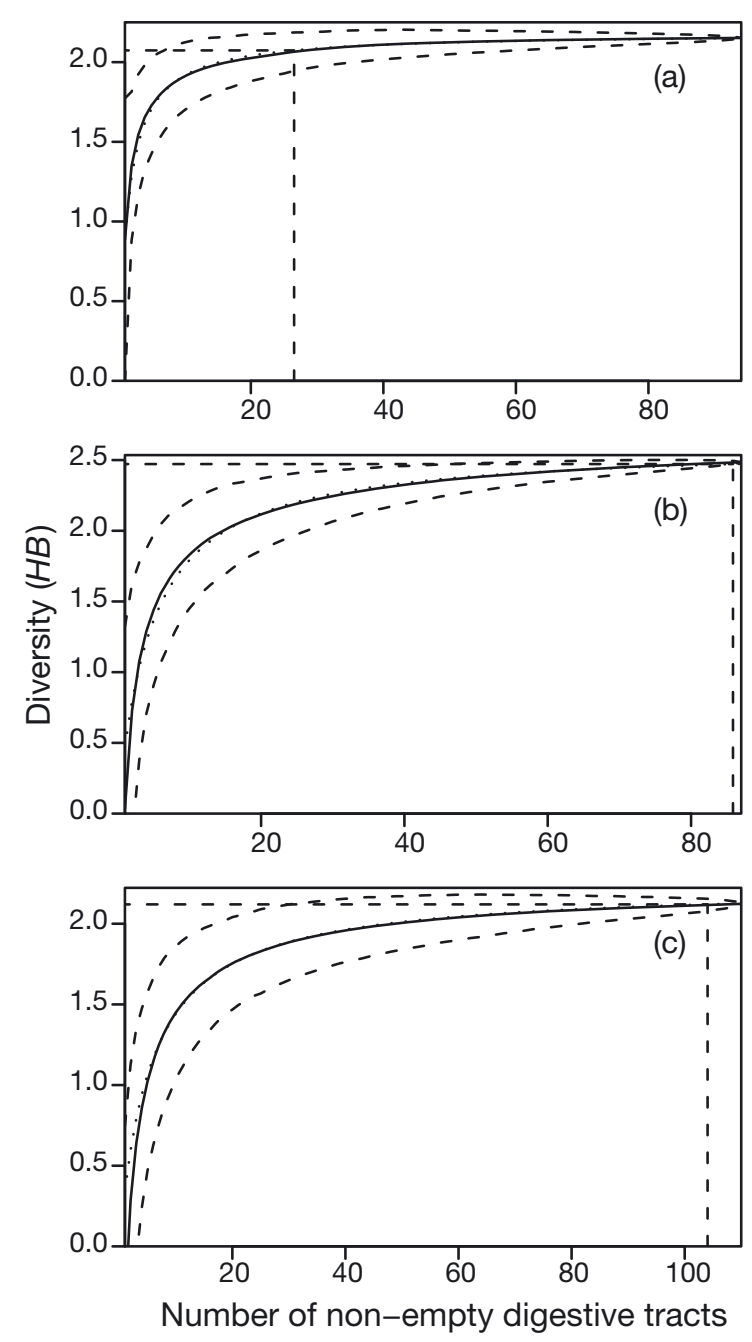

Fig. 2. Harriotta raleighana, Hydrolagus bemisi and Hydrolagus novaezealandiae. Cumulative diversity of prey categories (solid line) and 95\% CIs (broken lines) for (a) $H$. raleighana, (b) $H$. bemis and (c) $H$. novaezealandiae. The dotted line is the fitted curve from which asymptotic diversity was estimated. The vertical and horizontal broken lines mark $95 \%$ of the estimated asymptote

(Table 2). This model explained $20.1 \%$ of the variation in diet. The STF was strongly correlated with depth $\left(\mathrm{r}^{2}=0.86\right)$, and moderately correlated with bottom temperature $\left(r^{2}=0.56\right)$. Fish length was moderately negatively correlated with depth $\left(r^{2}=0.48\right)$.

SIMPER analysis showed that Polychaeta, Gastropoda, Bivalvia, Amphipoda, Brachyura and Anomura contributed most $(>10 \%)$ to the similarity within groups and dissimilarity between groups (Table 3). The diet of Harriotta raleighana was notably characterised by Gastropoda on the south flank of the Chatham Rise, Polychaeta and Anomura on the south flank and crest, Bivalvia on the crest and north flank, and Isopoda, 
Table 1. Harriotta raleighana. Digestive tract contents composition from individuals sampled from the Chatham Rise. Numbers in bold show the point estimates and $95 \%$ CIs (in parentheses) estimated by bootstrap resampling of the percentage frequency of occurrence $(\% F)$, percentage weight $(\% W)$, percentage number $(\% N)$ and percentage index of relative importance (\%IRI) for prey grouped at the taxonomic levels used in the multivariate analyses. Under each prey group, the numbers not in bold show the point estimates of the dietary statistics when calculated for all prey types (i.e. at full resolution), with the abiotic material and prey types that could not be allocated to one of the prey groups (and therefore excluded from multivariate analyses) listed at the bottom of the table

\begin{tabular}{|c|c|c|c|c|}
\hline & $\% F$ & $\% W$ & $\% N$ & $\%$ IRI \\
\hline Polychaeta & $83.0(70.1-93.0)$ & $36.7(22.2-51.9)$ & $17.6(9.7-24.8)$ & $34.9(21.9-45.1)$ \\
\hline Aphroditidae & 10.5 & 6.8 & 0.5 & 0.8 \\
\hline \multicolumn{5}{|l|}{ Onuphidae } \\
\hline Rhamphobrachium spp. & 2.1 & 0.4 & 0.1 & $<0.1$ \\
\hline Serpulidae & 5.3 & 0.6 & 0.2 & 0.1 \\
\hline Polychaeta unidentified & 77.9 & 9.0 & 13.7 & 18.8 \\
\hline Copepoda & $6.4(0-16.8)$ & $0.1(0-0.4)$ & $0.8(0-2.6)$ & $0.1(0-0.4)$ \\
\hline Copepoda unidentified & 6.3 & 0.1 & 0.7 & 0.1 \\
\hline Isopoda & $43.6(29.4-61.6)$ & $4.5(1.9-9.1)$ & $4.5(2.7-7.3)$ & $3.0(1.2-6.7)$ \\
\hline Arcturus spp. & 3.2 & $<0.1$ & 0.3 & $<0.1$ \\
\hline Gnathia spp. & 1.1 & $<0.1$ & 0.1 & $<0.1$ \\
\hline Acutiserolis spp. & 8.4 & 0.7 & 0.5 & 0.1 \\
\hline Isopoda unidentified & 33.7 & 1.3 & 2.9 & 1.5 \\
\hline Dendrobranchiata and Caridea & $5.3(0-14.9)$ & $0.1(0-0.3)$ & $0.5(0-1.7)$ & $<0.1(0-0.2)$ \\
\hline Crangonidae & 2.1 & $<0.1$ & 0.1 & $<0.1$ \\
\hline Dendrobranchiata and Caridea unidentified & 3.2 & $<0.1$ & 0.3 & $<0.1$ \\
\hline Anomura & $60.6(39.1-81.1)$ & $9.9(4.4-16.7)$ & $18.2(8.5-27.9)$ & $13.2 \quad(4.7-22.4)$ \\
\hline Munida gracilis & 57.9 & 3.6 & 14.8 & 11.3 \\
\hline Paguroidea & 4.2 & 0.9 & 0.2 & 0.1 \\
\hline Brachyura & $26.6(14.4-42.3)$ & $16.2(2.5-38.5)$ & $3.0(1.4-5.7)$ & $4.0(0.7-11.9)$ \\
\hline Pycnoplax victoriensis & 3.2 & 0.6 & 0.2 & $<0.1$ \\
\hline Pteropeltarion novaezelandiae & 1.1 & 0.6 & 0.1 & $<0.1$ \\
\hline Trichopeltarion fantasticum & 1.1 & 3.4 & 0.1 & $<0.1$ \\
\hline Brachyura unidentified & 25.3 & 2.8 & 2.2 & 1.3 \\
\hline Amphipoda & $71.3(55.1-85.4)$ & $2.8(1.8-4.3)$ & $13.6(9.4-18.0)$ & $9.1(4.8-14.2)$ \\
\hline Amphipoda unidentified & 70.5 & 1.3 & 11.3 & 9.4 \\
\hline Cumacea & $18.1(1.4-38.0)$ & $0.3(0.03-1.0)$ & $4.8(0.2-11.9)$ & $0.7(0.03-3.8)$ \\
\hline Cumacea unidentified & 17.9 & 0.2 & 4.0 & 0.8 \\
\hline Tanaidacea & $3.2(0-9.7)$ & $<0.1(0-0.2)$ & $0.2(0-0.5)$ & $<0.1(0-0.1)$ \\
\hline Tanaidacea unidentified & 3.2 & $<0.1$ & 0.2 & $<0.1$ \\
\hline Ostracoda & $12.8(5.3-22.4)$ & $0.2(0.1-0.5)$ & $1.2(0.4-2.3)$ & $0.1(0.02-0.4)$ \\
\hline Ostracoda unidentified & 12.6 & 0.1 & 1.0 & 0.1 \\
\hline Osteichthyes & $3.2(0-9.1)$ & $0.1(0-0.4)$ & $0.2(0-0.5)$ & $<0.1(0-0.1)$ \\
\hline Notophycis marginata & 1.1 & $<0.1$ & 0.1 & $<0.1$ \\
\hline Scales & 2.1 & $<0.1$ & 0.1 & $<0.1$ \\
\hline Asteroidea & $16.0(3.8-30.8)$ & $0.4(0.1-0.7)$ & $0.9(0.3-1.6)$ & $0.2(0.01-0.5)$ \\
\hline Asteroidea unidentified & 15.8 & 0.2 & 0.8 & 0.2 \\
\hline Echinoidea & $6.4(1.1-13.9)$ & $0.1(0.02-0.3)$ & $0.4(0.1-0.8)$ & $<0.1(0.001-0.1)$ \\
\hline Echinoidea unidentified & 6.3 & 0.1 & 0.3 & $<0.1$ \\
\hline Ophiuroidea & $4.3(0-10.3)$ & $0.1(0-0.2)$ & $0.2(0-0.6)$ & $<0.1(0-0.1)$ \\
\hline Ophiuroidea unidentified & 4.2 & $<0.1$ & 0.2 & $<0.1$ \\
\hline Foraminifera & $14.9(5.9-26.3)$ & $0.2(0.1-0.4)$ & $1.7(0.4-3.7)$ & $0.2(0.02-0.7)$ \\
\hline Pyrgo spp. & 9.5 & 0.1 & 0.6 & 0.1 \\
\hline Foraminifera unidentified & 5.3 & $<0.1$ & 0.8 & 0.1 \\
\hline Bivalvia & $60.6(40.0-80.0)$ & $11.1(3.6-19.5)$ & $9.3(5.1-14.1)$ & $9.6(3.0-17.7)$ \\
\hline Bivalvia unidentified & 60.0 & 5.1 & 7.7 & 8.1 \\
\hline Gastropoda & $89.4(80.0-96.6)$ & $13.7(4.5-30.3)$ & $22.1(15.2-31.6)$ & $24.8(14.0-41.7)$ \\
\hline Philine spp. & 37.9 & 0.3 & 5.6 & 2.4 \\
\hline Gastropoda unidentified & 75.8 & 5.9 & 12.4 & 14.8 \\
\hline Egg mass & 4.2 & 0.1 & 0.2 & $<0.1$ \\
\hline Cephalopoda & $1.1(0-4.7)$ & $<0.1(0-0.1)$ & $0.1(0-0.2)$ & $<0.1(0-0.01)$ \\
\hline Teuthoidea & 1.1 & $<0.1$ & 0.1 & $<0.1$ \\
\hline Scaphopoda & $10.6(2.8-22.2)$ & $0.1(0.03-0.4)$ & $0.6(0.1-1.3)$ & $0.1(0.04-0.3)$ \\
\hline Scaphopoda unidentified & 10.5 & 0.1 & 0.5 & 0.1 \\
\hline Protista & $1.1(0-4.6)$ & $<0.1(0-0.1)$ & $0.1(0-0.2)$ & $<0.1(0-0.01)$ \\
\hline Protista unidentified & 1.1 & $<0.1$ & 0.1 & $<0.1$ \\
\hline Salpida & $3.2(0-8.1)$ & $3.3(0-10.5)$ & $0.2(0-0.7)$ & $0.1(0-0.6)$ \\
\hline Salpida unidentified & 3.2 & 1.5 & 0.2 & 0.1 \\
\hline Abiotic, and unidentifiable prey & & & & \\
\hline Crustacea unidentified & 42.1 & 5.4 & 9.7 & 6.8 \\
\hline Mollusc unidentified & 11.6 & 0.1 & 3.9 & 0.5 \\
\hline Rocks & 2.1 & 0.5 & 0.1 & $<0.1$ \\
\hline Shell fragments & 44.2 & 43.3 & 2.1 & 21.3 \\
\hline Unidentifiable & 17.9 & 5.0 & 1.6 & 1.3 \\
\hline
\end{tabular}


Cumacea, and Brachyura on the north flank (Table 3). The diet of smaller fish $(29.2$ to $69.2 \mathrm{~cm}$ ) was characterised by relatively high percentages of Polychaeta, Gastropoda and small crustaceans (Cumacea, Isopoda and Amphipoda), while Anomura and Bivalvia were more important in larger fish (69.6 to $91.7 \mathrm{~cm}$ ) (Table 3). Anomura and Bivalvia characterised the diet to the east, Amphipoda the central region, and Polychaeta, Gastropoda and Isopoda the west (Table 3).

\section{Hydrolagus bemisi}

Of the 91 specimens of Hydrolagus bemisi examined, none had their digestive tracts empty of prey. The analyses of digestive tract contents led to the identifi-

Table 2. Harriotta raleighana. Results from the DistLM marginal models and the most parsimonious sequential model chosen using the best selection method (combined Akaike's information criterion and Bayesian information criterion).

STF: subtropical front. ${ }^{*} \mathrm{p}<0.05,{ }^{* *} \mathrm{p}<0.01,{ }^{* * *} \mathrm{p}<0.001$

\begin{tabular}{|lccc|}
\hline Predictor & Regression df & $\mathrm{p}$ & $\mathrm{r}^{2}$ \\
\hline Marginal test & & & \\
Latitude & 2 & $0.002^{* *}$ & 0.038 \\
Longitude & 2 & $0.001^{* * *}$ & 0.043 \\
Depth & 2 & $0.001^{* * *}$ & 0.078 \\
Fish length & 2 & $0.006^{* *}$ & 0.072 \\
Fish weight & 2 & $0.001^{* * *}$ & 0.061 \\
Sex & 2 & 0.221 & 0.015 \\
Bottom temperature & 2 & $0.001^{* * *}$ & 0.064 \\
Surface temperature & 2 & $0.001^{* * *}$ & 0.049 \\
West-east & 2 & $0.018^{*}$ & 0.027 \\
STF & 3 & $0.001^{* * *}$ & 0.123 \\
Sequential test & & & \\
STF & 3 & $0.001^{* * *}$ & 0.123 \\
+ Fish length & 4 & $0.001^{* * *}$ & 0.169 \\
+ Longitude & 5 & $0.002^{* *}$ & 0.201 \\
\hline
\end{tabular}

cation of 650 individual prey in 42 prey groups, with a total weight of $328 \mathrm{~g}$ (Table 4). The number of prey items per digestive tract varied between 1 and 56, with $55.2 \%$ of digestive tracts containing fewer than 5 prey items and $18.4 \%$ containing only a single prey item. Most digestive tracts $(78.2 \%)$ were one-quarter to three-quarters full, and $12.6 \%$ contained only trace amounts of prey. Four digestive tracts contained only well-digested or unidentifiable remains of prey $(4.4 \%)$, which left 87 for detailed analyses of diet. These specimens were sampled at depths between 371 and $792 \mathrm{~m}$, had a median length DF of $68.8 \mathrm{~cm}$ (range, 27.3 to $87.6 \mathrm{~cm})$, and a length $(\mathrm{cm})$ to weight $(W$, in $\mathrm{g})$ relationship of $W=0.0079 \times \mathrm{DF}^{2.922}\left(\mathrm{r}^{2}=0.98\right)$. H. bemisi had the highest diet diversity $(H B)$ of the 3 species, and the diversity of prey categories reached $95 \%$ of the estimated asymptote after 86 digestive tracts were examined, indicating that the sample was large enough to describe the diversity of the diet when using the assumed prey categorisation (Fig. $2 b$ ).

The diet of Hydrolagus bemisi was characterised by crabs and polychaete worms (Table 4 ). In terms of \%IRI and $\% W$, the diet was dominated by Brachyura, of which Pycnoplax victoriensis contributed $23.8 \%$ of the total prey weight. The next most important prey were polychaetes, which included Aphroditidae. Echinoidea were less frequently found, but accounted for more weight than did polychaetes $(10.1 \%)$, with the heart urchins Paramaretia peloria being most frequently identified, but Spatangus multispinus accounted for greater weight. Isopods were frequently found in the digestive tracts $(24.1 \%)$, but accounted for relatively little weight. Fish prey were found equally frequently, and were identified as such by the presence of scales and well-digested remains, but included the remains of the demersal Coelorinchus oliverianus and mesopelagic Lampanyctodes hectoris, both of which were identified from otoliths. Bivalvia, Amphipoda and

Table 3. Harriotta raleighana. Mean (SE) of standardised percent prey weight within the subtropical front (STF), fish length and longitude groups for the prey types together contributing at least $90 \%$ of the similarity percentages (SIMPER) within group similarity. SIMPER contribution to within group similarity: ${ }^{a} 4-10 \%,{ }^{b} 10-30 \%,{ }^{c}>30 \%$; n: sample size

\begin{tabular}{|c|c|c|c|c|c|c|c|c|c|}
\hline \multirow[t]{3}{*}{$\mathrm{n}$} & \multicolumn{3}{|c|}{ STF } & \multicolumn{3}{|c|}{ Fish length $(\mathrm{cm})$} & \multirow[b]{2}{*}{$\begin{array}{c}177.33- \\
179.85^{\circ} \mathrm{E}\end{array}$} & \multirow{2}{*}{$\begin{array}{l}\text { - Longitude } \\
177.88^{\circ} \mathrm{E}- \\
178.70^{\circ} \mathrm{W}\end{array}$} & \multirow[b]{2}{*}{$\begin{array}{c}178.47- \\
176.90^{\circ} \mathrm{W}\end{array}$} \\
\hline & South flank & Crest & North flank & $29.2-69.2$ & $69.6-74.8$ & $75.4-91.7$ & & & \\
\hline & 26 & 50 & 18 & 31 & 31 & 32 & 31 & 34 & 29 \\
\hline Brachyura & $1.2(1.0)$ & $5.4(2.1)$ & $19.9(7.7)^{b}$ & $4.1(1.8)$ & $7.2(3.6)$ & $9.6(4.3)$ & $4.1(1.7)$ & $9.4(4.7)$ & $7.2(2.5)$ \\
\hline Anomura & $8.0(2.8)^{\mathrm{a}}$ & $12.9(2.0)^{\mathrm{a}}$ & $2.8(1.3)$ & $5.6(1.7)$ & $9.2(2.4)^{\mathrm{b}}$ & $14.0(2.7)^{\mathrm{b}}$ & $4.7(1.4)$ & $8.6(2.5)^{\mathrm{a}}$ & $16.3(2.6)^{\mathrm{b}}$ \\
\hline Cumacea & $4.2(1.9)$ & $0.1(0.1)$ & $6.5(2.0)^{\mathrm{a}}$ & $6.2(1.8)^{\mathrm{a}}$ & $0.1(0.1)$ & $1.0(0.7)$ & $3.9(1.3)$ & $3.2(1.5)$ & $0.0(-)$ \\
\hline Polychaeta & $28.4(5.2)^{\mathrm{C}}$ & $30.6(3.4)^{\mathrm{C}}$ & $19.2(5.9)^{b}$ & $31.9(4.9)^{\mathrm{c}}$ & $27.0(4.3)^{\mathrm{b}}$ & $24.6(4.2)^{\mathrm{C}}$ & $32.3(5.1)^{\mathrm{C}}$ & $28.7(4.5)^{\mathrm{C}}$ & $22.0(3.5)^{b}$ \\
\hline Gastropoda & $34.0(4.8)^{\mathrm{c}}$ & $11.6(1.5)^{b}$ & $14.9(2.6)^{\mathrm{b}}$ & $22.8(3.4)^{\mathrm{c}}$ & $15.0(3.1)^{\mathrm{b}}$ & $17.6(3.3)^{\mathrm{b}}$ & $27.2(4.1)^{\mathrm{C}}$ & $13.7(2.4)^{\mathrm{b}}$ & $14.8(2.7)^{\mathrm{b}}$ \\
\hline Bivalvia & $3.5(1.5)$ & $18.0(2.9)^{\mathrm{b}}$ & $7.1(2.4)^{\mathrm{a}}$ & $4.9(1.8)$ & $19.0(3.7)^{b}$ & $12.0(2.9)^{\mathrm{b}}$ & $6.5(1.7)^{\mathrm{a}}$ & $11.0(1.7)^{\mathrm{a}}$ & $19.0(3.8)^{b}$ \\
\hline Amphipoda & $9.5(2.3)^{b}$ & $5.8(1.0)^{\mathrm{a}}$ & $9.3(2.0)^{b}$ & $10.1(1.6)^{b}$ & $4.5(1.0)^{\mathrm{a}}$ & $7.8(1.9)^{\mathrm{a}}$ & $6.2(1.2)^{\mathrm{a}}$ & $10.1(1.7)^{b}$ & $5.7(1.7)^{\mathrm{a}}$ \\
\hline Isopoda & $5.4(2.6)$ & $8.1(1.9)$ & $6.2(1.6)^{\mathrm{a}}$ & $7.6(2.4)^{\mathrm{a}}$ & $6.1(1.7)$ & $7.3(2.4)$ & $8.4(2.1)^{\mathrm{a}}$ & $6.4(2.0)$ & $6.2(2.5)$ \\
\hline
\end{tabular}


Table 4. Hydrolagus bemisi. Digestive tract contents composition from individuals sampled from the Chatham Rise. Numbers in bold show the point estimates and $95 \%$ CIs (in parentheses) estimated by bootstrap resampling of the percentage frequency of occurrence $(\% F)$, percentage weight $(\% W)$, percentage number $(\% N)$ and percentage index of relative importance (\%IRI) for prey grouped at the taxonomic levels used in the multivariate analyses. Under each prey group, the numbers not in bold show the point estimates of the dietary statistics when calculated for all prey types (i.e. at full resolution), with the abiotic material and prey types that could not

be allocated to one of the prey groups (and therefore excluded from multivariate analyses) listed at the bottom of the table

\begin{tabular}{|c|c|c|c|c|}
\hline & $\% F$ & $\% W$ & $\% N$ & $\%$ IRI \\
\hline Polychaeta & $44.8(36.2-64.3)$ & $8.5(3.3-24.6)$ & $12.6(7.9-22.7)$ & $17.4 \quad(8.2-43.7)$ \\
\hline Aphroditidae & 6.6 & 4.0 & 0.9 & 0.8 \\
\hline Polychaeta unidentified & 38.5 & 3.0 & 8.5 & 10.7 \\
\hline Cirripedia & $5.8(0-11.2)$ & $0.6(0-1.4)$ & $14.6(0-31.8)$ & $1.6(0-4.8)$ \\
\hline Cirripedia unidentified & 5.5 & 0.5 & 10.9 & 1.5 \\
\hline Isopoda & $24.1(13.6-43.5)$ & $2.5(0.9-6.9)$ & $10.7(6.1-22.0)$ & $5.9(2.2-15.5)$ \\
\hline Acutiserolis spp. & 5.5 & 0.1 & 0.8 & 0.1 \\
\hline Isopoda unidentified & 17.6 & 2.0 & 7.2 & 3.9 \\
\hline Euphausiacea & $1.2(0-6.0)$ & $<0.1(0-0.04)$ & $0.2(0-1.1)$ & $<0.1(0-0.1)$ \\
\hline Euphausiacea unidentified & 1.1 & $<0.1$ & 0.2 & $<0.1$ \\
\hline Dendrobranchiata and Caridea & $3.5(0-7.9)$ & $0.6(0-1.5)$ & $0.8(0-2.2)$ & $0.1(0-0.5)$ \\
\hline Pasiphaea spp. & 2.2 & 0.3 & 0.3 & $<0.1$ \\
\hline Dendrobranchiata and Caridea unidentified & 2.2 & 0.2 & 0.3 & $<0.1$ \\
\hline Astacidea & $1.2(0-4.6)$ & $1.3(0-4.3)$ & $0.2(0-0.7)$ & $<0.1(0-0.3)$ \\
\hline Metanephrops challengeri & 1.1 & 1.1 & 0.2 & $<0.1$ \\
\hline Anomura & $17.2(7.5-30.4)$ & $8.0(2.2-18.5)$ & $3.9(1.8-8.1)$ & $3.8(0.7-11.3)$ \\
\hline Munida gracilis & 13.2 & 2.0 & 1.9 & 1.2 \\
\hline Paguroidea & 16.5 & 6.7 & 2.8 & 3.8 \\
\hline Sympagurus dimorphous & 2.2 & 2.8 & 0.6 & 0.2 \\
\hline Brachyura & $40.2(22.5-57.7)$ & $48.0(24.6-60.4)$ & $13.0(6.3-17.9)$ & $45.2(14.1-59.7)$ \\
\hline Pycnoplax victoriensis & 23.1 & 23.8 & 6.0 & 16.6 \\
\hline Teratomaia richardsoni & 1.1 & 1.5 & 0.2 & $<0.1$ \\
\hline Trichopeltarion fantasticum & 4.4 & 7.5 & 0.8 & 0.9 \\
\hline Brachyura unidentified & 16.5 & 6.7 & 2.8 & 3.8 \\
\hline Amphipoda & $16.1(7.5-30.7)$ & $0.2(0.1-0.5)$ & $4.9(1.9-10.2)$ & $1.5(0.3-5.1)$ \\
\hline Vibiliidae & 1.1 & $<0.1$ & 0.5 & $<0.1$ \\
\hline Amphipoda unidentified & 14.3 & 0.1 & 3.2 & 1.2 \\
\hline Cumacea & $1.2(0-6.3)$ & $<0.1(0-0.02)$ & $0.2(0-1.2)$ & $<0.1(0-0.1)$ \\
\hline Cumacea unidentified & 1.1 & $<0.1$ & 0.2 & $<0.1$ \\
\hline Osteichthyes & $24.1(11.4-34.3)$ & $2.8(0.4-7.5)$ & $6.4(2.8-10.6)$ & $4.1(0.7-8.8)$ \\
\hline Coelorinchus oliverianus & 1.1 & $<0.1$ & 0.2 & $<0.1$ \\
\hline Lampanyctodes hectoris & 3.3 & $<0.1$ & 0.5 & $<0.1$ \\
\hline Scales & 5.5 & 0.1 & 0.9 & 0.1 \\
\hline Fishes unidentified & 20.9 & 2.2 & 3.2 & 2.7 \\
\hline Ascidiacea & $2.3(0-6.1)$ & $0.8(0-2.1)$ & $0.4(0-1.2)$ & $0.1(0-0.3)$ \\
\hline Ascidiacea unidentified & 2.2 & 0.6 & 0.3 & 0.1 \\
\hline Cnidaria & $9.2(2.1-20.5)$ & $2.3(0.03-6.6)$ & $1.7(0.4-3.5)$ & $0.7(0.03-2.9)$ \\
\hline \multicolumn{5}{|l|}{ Anthozoa } \\
\hline Coraliidae & 1.1 & $<0.1$ & 0.2 & $<0.1$ \\
\hline Pennatulacea & 1.1 & $<0.1$ & 0.2 & $<0.1$ \\
\hline Hydrozoa unidentified & 6.6 & 1.8 & 0.9 & 0.4 \\
\hline Asteroidea & $6.9(0-17.2)$ & $1.0(0-3.4)$ & $1.2(0-3.3)$ & $0.3(0-1.7)$ \\
\hline Asteroidea unidentified & 6.59 & 0.85 & 0.92 & 0.28 \\
\hline Echinoidea & $20.7(7.9-36.8)$ & $10.1(2.0-23.7)$ & $4.3(1.9-7.3)$ & $5.5(0.9-14.0)$ \\
\hline Paramaretia peloria & 7.7 & 1.2 & 1.2 & 0.5 \\
\hline Spatangus multispinus & 1.1 & 3.0 & 0.2 & 0.1 \\
\hline Echinoidea unidentified & 11.0 & 4.1 & 1.9 & 1.6 \\
\hline Foraminifera & $1.2(0-6.3)$ & $<0.1(0-0.1)$ & $0.2(0-1.3)$ & $<0.1(0-0.2)$ \\
\hline Foraminifera unidentified & 1.1 & $<0.1$ & 0.2 & $<0.1$ \\
\hline Bivalvia & $16.1(7.2-28.3)$ & $1.0(0.2-2.7)$ & $5.1(2.0-10.8)$ & $1.8(0.3-5.3)$ \\
\hline Bivalvia unidentified & 13.2 & 0.8 & 3.4 & 1.3 \\
\hline Gastropoda & $24.1(14.6-42.3)$ & $1.3(0.4-4.3)$ & $6.8(4.1-11.9)$ & $3.6(1.4-9.6)$ \\
\hline Gastropoda unidentified & 23.1 & 1.1 & 5.1 & 3.4 \\
\hline Cephalopoda & $2.3(0-7.4)$ & $<0.1(0-0.1)$ & $0.4(0-1.5)$ & $<0.1(0-0.2)$ \\
\hline Histioteuthis spp. & 1.1 & $<0.1$ & 0.2 & $<0.1$ \\
\hline Cephalopoda unidentified & 1.1 & $<0.1$ & 0.2 & $<0.1$ \\
\hline Porifera & $3.5(0-9.8)$ & $0.3(0-0.6)$ & $3.5(0-9.3)$ & $0.2(0-1.4)$ \\
\hline Porifera unidentified & 3.3 & 0.2 & 2.6 & 0.2 \\
\hline Protista & $3.5(0-8.2)$ & $1.7(0-4.8)$ & $0.6(0-1.4)$ & $0.2(0-0.7)$ \\
\hline Protista unidentified & 3.3 & 1.4 & 0.5 & 0.2 \\
\hline Salpida & $25.3(12.0-36.8)$ & $9.0(3.2-15.6)$ & $8.2(3.0-15.3)$ & $8.0(1.3-18.1)$ \\
\hline Iasis zonaria & 1.1 & 0.5 & 0.5 & $<0.1$ \\
\hline Salpida unidentified & 23.1 & 6.9 & 5.7 & 7.0 \\
\hline \multicolumn{5}{|l|}{ Abiotic, and unidentifiable prey } \\
\hline Crustacea unidentified & 50.6 & 7.6 & 13.5 & 25.9 \\
\hline Shell fragments & 26.4 & 0.6 & 6.0 & 4.2 \\
\hline Unidentifiable & 28.6 & 9.6 & 6.2 & 10.8 \\
\hline
\end{tabular}


Anomura were all similarly frequent, but Anomura accounted for a relatively high weight $(8.0 \%)$ due to their relatively large size.

The DistLM analysis indicated significant relationships between the diet of Hydrolagus bemisi and several of the predictors, with the most parsimonious model having the predictors bottom temperature and fish weight (Table 5). This model explained $17.6 \%$ of the variation in diet. Bottom temperature was strongly positively correlated with latitude $\left(\mathrm{r}^{2}=0.76\right)$ and longitude $\left(\mathrm{r}^{2}=0.71\right)$, negatively correlated with depth $\left(\mathrm{r}^{2}=\right.$ 0.74 ), and moderately positively correlated with surface temperature $\left(\mathrm{r}^{2}=0.59\right)$ and STF $\left(\mathrm{r}^{2}=0.51\right)$. There was a weak positive correlation between fish weight and bottom temperature $\left(\mathrm{r}^{2}=0.34\right)$.

SIMPER analysis showed that Brachyura, Polychaeta, Osteichthyes and Salpidae contributed most

Table 5. Hydrolagus bemisi. Results from the DistLM marginal models and the most parsimonious sequential model chosen using the best selection method (combined Akaike's information criterion and Bayesian information criterion).

STF: subtropical front. ${ }^{*} \mathrm{p}<0.05,{ }^{* *} \mathrm{p}<0.01,{ }^{* * *} \mathrm{p}<0.001$

\begin{tabular}{|lccc|}
\hline Predictor & Regression df & $\mathrm{p}$ & $\mathrm{r}^{2}$ \\
\hline Marginal test & & & \\
Survey & 3 & $0.001^{* * *}$ & 0.111 \\
Latitude & 2 & $0.001^{* * *}$ & 0.122 \\
Longitude & 2 & $0.001^{* * *}$ & 0.112 \\
Depth & 2 & $0.001^{* * *}$ & 0.080 \\
Fish length & 2 & $0.006^{* *}$ & 0.040 \\
Fish weight & 2 & $0.001^{* * *}$ & 0.070 \\
Sex & 2 & $0.794^{* *}$ & 0.006 \\
Bottom temperature & 2 & $0.001^{* * *}$ & 0.147 \\
Surface temperature & 2 & $0.001^{* * *}$ & 0.064 \\
West-east & 2 & $0.001^{* * *}$ & 0.101 \\
STF & 3 & $0.001^{* *}$ & 0.094 \\
Sequential test & & & \\
Bottom temperature & 2 & $0.001^{* * *}$ & 0.147 \\
+ Fish weight & 3 & $0.011^{*}$ & 0.176 \\
\hline
\end{tabular}

( $>10 \%$ ) to the similarity within groups and dissimilarity between groups (Table 6). The diet was dominated by Brachyura in warmer water and in larger fish, and Polychaeta and Salpidae in cooler water and in smaller fish (Table 6). The diet was characterised also by Echinoidea and Anomura in warmer water, Osteichthyes in intermediate temperature water and Gastropoda in cooler water (Table 6). As fish increased in size, Polychaeta and small crustaceans (Amphipoda and Isopoda) became less important and Brachyura became more important, with Salpidae, Osteichthyes and Anomura being most important in intermediate sized fish (Table 6).

\section{Hydrolagus novaezealandiae}

Of 148 specimens of Hyrolagus novazealandiae examined, 11 had their digestive tract empty of prey $(7.4 \%)$. The analyses of digestive tract contents led to the identification of 617 individual prey in 32 prey groups, with a total weight of $387 \mathrm{~g}$ (Table 7). The number of prey items per digestive tract varied between 1 and 11, with $86.4 \%$ of digestive tracts containing fewer than 5 prey items, and $36.4 \%$ containing only a single prey item. Most digestive tracts (56.4\%) were one-quarter to three-quarters full, and $40.0 \%$ contained only trace amounts of prey. Twenty-seven digestive tracts contained only well-digested or unidentifiable remains of prey $(18.2 \%)$, which left 110 for detailed analyses of diet. These specimens were sampled at depths between 219 and $570 \mathrm{~m}$, had a median DF length of $57.8 \mathrm{~cm}$ (range, 31.2 to $72.9 \mathrm{~cm}$ ), and a length $(\mathrm{cm})$ to weight $(W$, in $\mathrm{g})$ relationship of $W=0.0022 \times \mathrm{DF}^{3.239}\left(\mathrm{r}^{2}=0.98\right)$. The diversity of prey categories reached $95 \%$ of the estimated asymptote after 105 digestive tracts were examined (Fig. 2c), indicating that the sample was large enough to describe

Table 6. Hydrolagus bemisi. Mean (SE) of standardised percent prey weight within the bottom temperature and fish weight groups for the prey types together contributing at least $90 \%$ of the similarity percentages (SIMPER) within group similarity. SIMPER contribution to within group similarity: ${ }^{\mathrm{a}} 3-10 \%,{ }^{\mathrm{b}} 10-30 \%,{ }^{\mathrm{c}}>30 \%$; n: sample size

\begin{tabular}{|lcccccc|}
\hline n & \multicolumn{3}{c}{ Bottom temperature $\left.{ }^{\circ} \mathrm{C}\right)$} & \multicolumn{3}{c|}{ Fish weight $(\mathrm{g})^{2}$} \\
& $6.0-7.0$ & $7.2-7.7$ & $8.0-8.7$ & $140-1485$ & $1565-2135$ & $2140-3560$ \\
& 25 & 33 & 29 & 29 & 29 & 29 \\
\hline Brachyura & $3.2(3.1)$ & $24.1(7.0)^{\mathrm{c}}$ & $48.3(7.0)^{\mathrm{c}}$ & $10.8(4.5)^{\mathrm{a}}$ & $16.9(6.0)^{\mathrm{b}}$ & $50.7(7.8)^{\mathrm{c}}$ \\
Anomura & $0.2(0.2)$ & $2.7(1.5)$ & $9.9(3.4)^{\mathrm{a}}$ & $2.9(2.9)$ & $5.3(2.3)^{\mathrm{a}}$ & $4.9(0.3)$ \\
Polychaeta & $33.5(7.7)^{\mathrm{c}}$ & $24.6(7.1)^{\mathrm{c}}$ & $3.6(2.2)$ & $31.1(7.1)^{\mathrm{c}}$ & $16.9(5.9)^{\mathrm{b}}$ & $12.4(5.8)^{\mathrm{a}}$ \\
Gastropoda & $5.4(2.8)^{\mathrm{a}}$ & $0.6(0.4)$ & $4.4(3.5)$ & $6.2(3.8)$ & $1.3(0.8)$ & $2.2(1.7)$ \\
Amphipoda & $5.5(4.0)$ & $5.2(3.6)$ & $0.1(0.1)$ & $10.3(5.1)^{\mathrm{a}}$ & $0.2(0.1)$ & $0.2(0.1)$ \\
Isopoda & $5.9(3.4)$ & $6.1(3.5)$ & $0.6(0.3)$ & $9.5(4.3)^{\mathrm{a}}$ & $4.3(2.2)^{\mathrm{a}}$ & $0.7(0.5)$ \\
Echinoidea & $4.0(3.9)$ & $0.1(0.1)$ & $10.8(3.8)^{\mathrm{a}}$ & $3.4(2.9)$ & $4.3(2.6)$ & $6.6(3.6)^{\mathrm{a}}$ \\
Osteichthyes & $2.3(1.7)$ & $12.7(4.9)^{\mathrm{b}}$ & $0.7(0.4)$ & $0.5(0.4)$ & $15.1(5.3)^{\mathrm{b}}$ & $1.5(1.2)$ \\
Salpidae & $33.1(8.2)^{\mathrm{c}}$ & $11.9(4.1)^{\mathrm{b}}$ & $3.4(2.6)$ & $16.0(6.5)^{\mathrm{b}}$ & $24.3(6.2)^{\mathrm{c}}$ & $12.4(5.8)$ \\
\hline
\end{tabular}


Table 7. Hydrolagus novaezealandiae. Digestive tract contents composition from individuals sampled from the Chatham Rise. Numbers in bold show the point estimates and $95 \%$ CIs (in parentheses) estimated by bootstrap resampling of the percentage frequency of occurrence $(\% F)$, percentage weight $(\% W)$, percentage number $(\% N)$ and percentage index of relative importance $(\%$ IRI) for prey grouped at the taxonomic levels used in the multivariate analyses. Under each prey group the normal text lines show the point estimates of the dietary statistics when calculated for all prey types (i.e. at full resolution), with the abiotic material and prey types that could not be allocated to one of the prey groups (and therefore excluded from multivariate analyses) listed at the bottom of the table

\begin{tabular}{|c|c|c|c|c|}
\hline & $\% F$ & $\% W$ & $\% N$ & $\%$ IRI \\
\hline Polychaeta & $20.9(11.3-32.7)$ & $1.3(0.5-3.8)$ & $11.0(6.8-18.8)$ & $4.3(1.2-11.2)$ \\
\hline Eunice spp. & 0.7 & $<0.1$ & 0.2 & $<0.1$ \\
\hline Hyalinoecia tubicola & 0.7 & $<0.1$ & 0.2 & $<0.1$ \\
\hline Polychaeta unidentified & 15.3 & 1.1 & 5.0 & 3.0 \\
\hline Isopoda & $6.4(2.4-17.4)$ & $0.3(0.1-0.8)$ & $2.7(1.0-6.9)$ & $0.3(0.04-1.9)$ \\
\hline Acutiserolis spp. & 2.9 & 0.1 & 0.7 & 0.1 \\
\hline Isopoda unidentified & 2.2 & 0.1 & 0.7 & 0.1 \\
\hline Dendrobranchiata and Caridea & $1.8(0-6.5)$ & $0.2(0-0.9)$ & $0.7(0-2.3)$ & $<0.1(0-0.3)$ \\
\hline Pasiphaea spp. & 0.7 & $<0.1$ & 0.2 & $<0.1$ \\
\hline Dendrobranchiata and Caridea unidentified & 0.7 & 0.2 & 0.2 & $<0.1$ \\
\hline Anomura & $23.6(19.4-44.6)$ & $7.4(1.8-16.6)$ & $12.0(7.6-19.5)$ & $7.7(3.1-21.5)$ \\
\hline Munida gracilis & 15.3 & 6.1 & 4.1 & 4.9 \\
\hline Paguroidea & 4.4 & 0.4 & 1.8 & 0.3 \\
\hline Brachyura & $40.9(28.0-64.1)$ & $67.8(46.0-87.7)$ & $27.1(13.2-39.3)$ & $64.9(38.8-83.1)$ \\
\hline Leptomithrax longipes & 0.7 & 1.0 & 0.2 & $<0.1$ \\
\hline Neommatocarcinus huttoni & 8.8 & 3.6 & 5.4 & 2.5 \\
\hline Paromola petterdi & 0.7 & 0.5 & 0.2 & $<0.1$ \\
\hline Pycnoplax victoriensis & 15.3 & 40.8 & 4.7 & 22.1 \\
\hline Brachyura unidentified & 8.8 & 13.3 & 2.8 & 4.5 \\
\hline Amphipoda & $4.6(0-9.7)$ & $0.1(0-0.4)$ & $2.3(0-6.4)$ & $0.2(0-1.0)$ \\
\hline Amphipoda unidentified & 3.7 & 0.1 & 1.1 & 0.1 \\
\hline Cumacea & $0.9(0-3.9)$ & $<0.1(0-0.01)$ & $0.7(0-2.6)$ & $<0.1(0-0.2)$ \\
\hline Cumacea unidentified & 0.7 & $<0.1$ & 0.3 & $<0.1$ \\
\hline Osteichthyes & $18.2(10.6-29.4)$ & $0.3(0.1-0.9)$ & $7.0(4.0-11.0)$ & $2.2(0.7-5.5)$ \\
\hline Scales & 6.6 & 0.1 & 1.6 & 0.4 \\
\hline Fishes unidentified & 8.0 & 0.2 & 1.8 & 0.5 \\
\hline Asteroidea & $0.9(0-5.1)$ & $0.9(0-5.1)$ & $0.3(0-1.7)$ & $<0.1(0-0.5)$ \\
\hline Asteroidea unidentified & 0.7 & 0.8 & 0.2 & $<0.1$ \\
\hline Echinoidea & $30.0(11.8-43.6)$ & $15.0(0.3-32.8)$ & $12.7(4.2-17.5)$ & $13.9 \quad(0.8-27.9)$ \\
\hline Paramaretia peloria & 8.8 & 10.9 & 2.3 & 3.7 \\
\hline Spatangus multispinus & 2.9 & 0.5 & 0.7 & 0.1 \\
\hline Echinoidea unidentified & 13.9 & 1.6 & 3.2 & 2.1 \\
\hline Ophiuroidea & $11.8(4.1-20.2)$ & $1.5(0.1-4.8)$ & $4.4(1.4-6.9)$ & $1.2(0.1-3.3)$ \\
\hline Ophiacantha spp. & 1.5 & 1.0 & 0.3 & 0.1 \\
\hline Ophiuroidea unidentified & 8.0 & 0.3 & 1.8 & 0.5 \\
\hline Bivalvia & $6.4(2.3-14.7)$ & $0.1(0.04-0.6)$ & $3.0(1.0-6.2)$ & $0.3(0.04-1.5)$ \\
\hline Bivalvia unidentified & 5.1 & 0.1 & 1.5 & 0.3 \\
\hline Gastropoda & $18.2(3.8-29.0)$ & $0.8(0.04-1.5)$ & $9.7(2.1-14.8)$ & $3.2(0.1-8.0)$ \\
\hline Gastropoda unidentified & 14.6 & 0.7 & 4.7 & 2.5 \\
\hline Scaphopoda & $0.9(0-3.4)$ & $<0.1(0-0.01)$ & $0.3(0-1.2)$ & $<0.1(0-0.1)$ \\
\hline Scaphopoda unidentified & 0.7 & $<0.1$ & 0.2 & $<0.1$ \\
\hline Salpida & $10.0(4.8-23.5)$ & $4.3(1.1-15.1)$ & $6.0(2.6-15.0)$ & $1.7(0.3-9.7)$ \\
\hline Salpida unidentified & 8.0 & 3.8 & 2.9 & 1.7 \\
\hline \multicolumn{5}{|l|}{ Abiotic, and unidentifiable prey } \\
\hline Annelida unidentified & 0.7 & $<0.1$ & 0.2 & $<0.1$ \\
\hline Crustacea unidentified & 33.6 & 6.0 & 10.7 & 17.8 \\
\hline Shell fragments & 16.8 & 0.3 & 30.2 & 16.2 \\
\hline Sand & 6.6 & 0.2 & 1.5 & 0.3 \\
\hline Unidentifiable & 33.6 & 6.3 & 9.1 & 16.4 \\
\hline
\end{tabular}

the diversity of the diet when using the assumed prey categorisation.

The diet of Hydrolagus novaezealandiae was characterised by crabs and sea urchins (Table 7). In terms of \%IRI and $\% W$, the diet was dominated by Brachyura, in particular Pycnoplax victoriensis, which was identified in $15.3 \%$ of the digestive tracts, but being a relatively large prey contributed $40.8 \%$ of the total prey weight. The next most important prey were Echinoidea, of which Paramaretia peloria was most frequently identified. Molluscs, and in particular gastropods, were identified quite frequently, but accounted for relatively little weight, even when the unidentifiable shell fragments were included. Fish 
prey were found in $18.2 \%$ of the digestive tracts and were identified as such by the presence of scales and occasional well-digested remains. Anomura occurred in $23.6 \%$ of the digestive tracts, and accounted for a relatively high weight $(7.4 \%)$ due to their relatively large size. Polychaetes were also frequently found $(20.9 \%)$, but most could not be identified further, and they accounted for relatively little weight.

Only one sample was collected from a depth $>499 \mathrm{~m}$, so this was added to the crest sample. The DistLM analysis indicated significant relationships between the Hydrolagus novaezealandiae diet and several of the predictors, with the most parsimonious model having the predictors STF, west-east and fish weight (Table 8). This model explained $17.2 \%$ of the variation in diet; the majority of the variability in diet could not

Table 8. Hydrolagus novaezealandiae. Results from the DistLM marginal models and the most parsimonious sequential model chosen using the best selection method (combined Akaike's information criterion and Bayesian information criterion). STF: subtropical front. ${ }^{*} \mathrm{p}<0.05,{ }^{* *} \mathrm{p}<0.01,{ }^{* * *} \mathrm{p}<0.001$

\begin{tabular}{|lccc|}
\hline Predictor & Regression df & $\mathrm{p}$ & $\mathrm{r}^{2}$ \\
\hline Marginal test & & & \\
Survey & 3 & 0.171 & 0.025 \\
Latitude & 2 & $0.045^{* *}$ & 0.019 \\
Longitude & 2 & $0.007^{* *}$ & 0.026 \\
Depth & 2 & $0.001^{* * *}$ & 0.058 \\
Fish length & 2 & $0.001^{* * *}$ & 0.045 \\
Fish weight & 2 & $0.001^{* * *}$ & 0.055 \\
Sex & 2 & 0.968 & 0.002 \\
Bottom temperature & 2 & $0.001^{* * *}$ & 0.057 \\
Surface temperature & 2 & 0.258 & 0.011 \\
West-east & 2 & $0.002^{* *}$ & 0.037 \\
STF & 3 & $0.001^{* * *}$ & 0.092 \\
Sequential test & & & \\
STF & 2 & $0.001^{* * *}$ & 0.092 \\
+ West-east & 4 & $0.001^{* * *}$ & 0.138 \\
+ Fish weight & 5 & $0.001^{* * *}$ & 0.172 \\
\hline
\end{tabular}

be explained by the available predictors. The STF was strongly correlated with depth $\left(\mathrm{r}^{2}=0.88\right)$ and moderately correlated with bottom temperature $\left(r^{2}=0.64\right)$. There was no correlation between fish weight and depth $\left(r^{2}=0.01\right)$.

SIMPER analysis showed that Brachyura, Anomura, Polychaeta, Gastropoda, Echinoidea and Salpidae contributed most $(>10 \%)$ to the similarity within groups and dissimilarity between groups (Table 9). The diet of Hyrolagus novazealandiae on the crest of Chatham Rise was dominated by Brachyura, and that on the banks by a wider variety of prey, predominantly Echinoidea, Polychaeta, Gastropoda and Anomura (Table 9). Brachyura and Echinoidea were characteristic of the diet on the east Chatham Rise, and Brachyura, Anomura, Polychaeta and Salpidae on the west Chatham Rise (Table 9). As fish got larger, the diet was increasingly dominated by Brachyura and Anomura, and less by Echinoidea, Ophiuroidea, Gastropoda and Osteichthyes (Table 9).

\section{Dietary overlap}

The cluster analysis at species level split Harriotta raleighana from the 2 Hydrolagus species, $H$. bemisi and $H$. novazealandiae, at $62 \%$ similarity, and then split the 2 Hydrolagus species at $72 \%$ similarity.

Following the species-specific analyses of diet, the samples were split into 7 groups: Harriotta raleighana was split into 3 STF groups: crest, southern flank and northern flank. Hydrolagus bemisi was split into warm and cool bottom temperature groups: 8.0 to $8.7^{\circ} \mathrm{C}$, and 6.0 to $7.7^{\circ} \mathrm{C}$, respectively. Hydrolagus novaezealandiae was split into 2 STF groups: bank and crest. The cluster analysis at the group level found that some interspecific similarities were greater than intraspecific similarities. There was a greater similarity between the diets of $H$. bemisi in cool water and $H$.

Table 9. Hydrolagus novaezealandiae. Mean (SE) of standardised percent prey weight within the subtropical front (STF), west-east and fish weight group, for the prey types together contributing at least $90 \%$ of the similarity percentages (SIMPER) within group similarity. SIMPER contribution to within group similarity: ${ }^{\mathrm{a}} 3-10 \%,{ }^{\mathrm{b}} 10-30 \%,{ }^{\mathrm{c}}>30 \%$; n: sample size

\begin{tabular}{|lccccrrr|}
\hline $\mathrm{n}$ & \multicolumn{2}{c}{ STF } & \multicolumn{2}{c}{ West-east } & \multicolumn{2}{c|}{ Fish weight (g) } \\
& Bank & Crest & West & East & $145-865$ & $880-1355$ & $1395-2415$ \\
& 52 & 58 & 46 & 64 & 36 & 36 & 38 \\
\hline Brachyura & $11.0(4.1)^{\mathrm{a}}$ & $48.0(5.9)^{\mathrm{c}}$ & $31.0(6.2)^{\mathrm{c}}$ & $30.0(5.4)^{\mathrm{c}}$ & $10.0(4.7)^{\mathrm{a}}$ & $34.0(7.3)^{\mathrm{c}}$ & $46.0(7.5)^{\mathrm{c}}$ \\
Anomura & $12.9(4.2)^{\mathrm{b}}$ & $7.6(7.8)^{\mathrm{a}}$ & $14.6(4.2)^{\mathrm{b}}$ & $6.9(2.9)$ & $5.5(3.8)$ & $13.9(5.2)^{\mathrm{b}}$ & $11.0(3.8)^{\mathrm{b}}$ \\
Polychaeta & $14.0(4.1)^{\mathrm{b}}$ & $6.4(3.0)$ & $16.0(5.2)^{\mathrm{b}}$ & $5.7(2.4)$ & $16.0(5.3)^{\mathrm{b}}$ & $3.7(2.6)$ & $10.0(4.4)^{\mathrm{a}}$ \\
Gastropoda & $12.4(4.0)^{\mathrm{b}}$ & $2.0(1.7)$ & $3.7(2.6)$ & $9.3(3.2)^{\mathrm{a}}$ & $7.9(3.7)^{\mathrm{a}}$ & $8.1(4.5)$ & $5.0(3.1)$ \\
Echinoidea & $22.0(5.2)^{\mathrm{c}}$ & $13.0(4.1)^{\mathrm{a}}$ & $5.3(3.1)$ & $26.0(4.9)^{\mathrm{c}}$ & $26.0(6.6)^{\mathrm{c}}$ & $16.0(5.4)^{\mathrm{b}}$ & $10.0(4.8)$ \\
Osteichthyes & $7.0(3.0)$ & $6.0(3.0)$ & $7.0(4.0)$ & $7.0(3.0)^{\mathrm{a}}$ & $9.0(4.0)^{\mathrm{a}}$ & $8.0(4.0)$ & $3.0(3.0)$ \\
Ophiuroidea & $3.9(2.7)$ & $5.6(2.8)$ & $2.5(2.2)$ & $6.5(2.9)$ & $10.6(5.1)^{\mathrm{a}}$ & $3.9(2.9)$ & $0.2(0.1)$ \\
Salpidae & $9.5(4.1)^{\mathrm{a}}$ & $5.6(2.9)$ & $15.0(5.2)^{\mathrm{b}}$ & $1.9(1.6)$ & $2.8(2.8)$ & $11.0(5.2)^{\mathrm{a}}$ & $8.5(4.3)$ \\
\hline
\end{tabular}




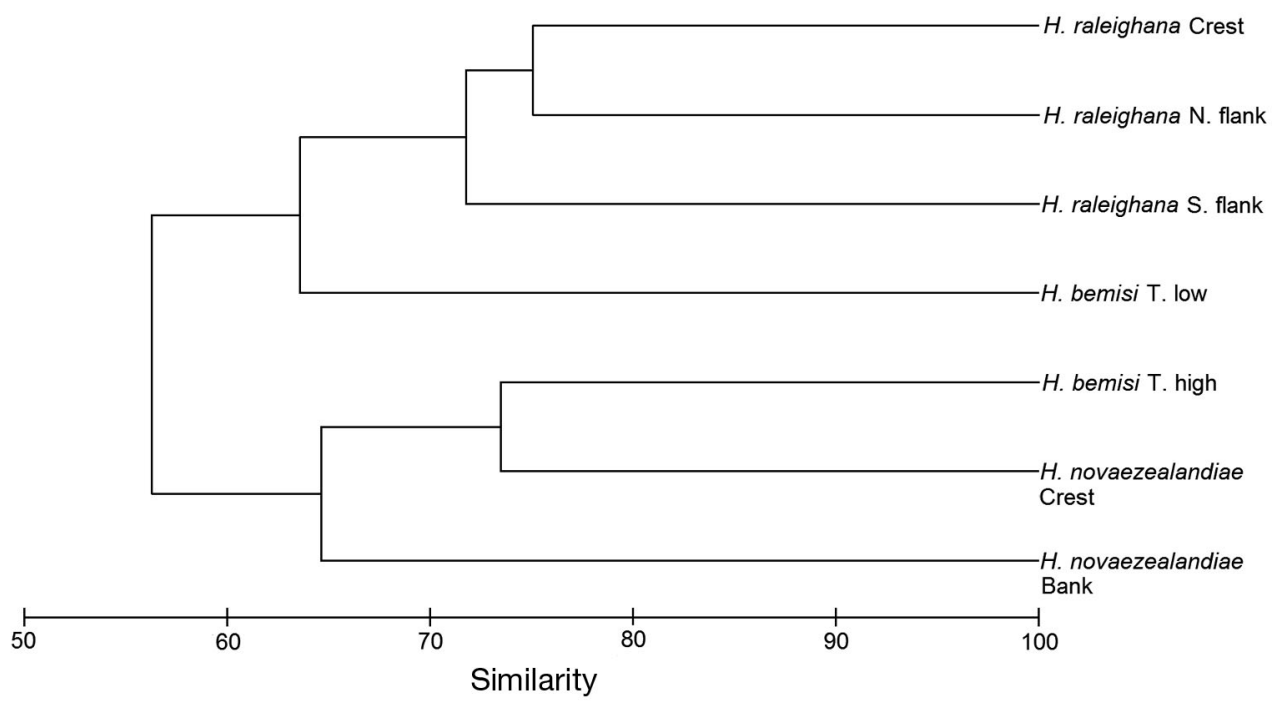

Fig. 3. Harriotta raleighana, Hydrolagus bemisi and Hydrolagus novaezealandiae. Dendrogram of group-averaged cluster analysis of Bray-Curtis dissimilarities based on percent square-root transformed weight $(\% W)$ of the diet for sample subgroups of all 3 species. N. flank: northern flank; S. flank: southern flank; T. low: low temperature, $6.0-7.7^{\circ} C_{i} \mathrm{~T}$. high: high temperature, $8.0-8.7^{\circ} \mathrm{C}$

raleighana, than between $H$. bemisi in cool water and $H$. bemisi in warm water (Fig. 3). There was a greater similarity between the diets of $H$. novaezealandiae on the crest and $H$. bemisi in warm water than between $H$. novaezealandiae on the crest and $H$. novaezealandiae on the banks. The greatest similarity in diet was between $H$. raleighana groups on the crest and northern flank $(75 \%)$, and between $H$. novaezealandiae on the crest and $H$. bemisi in warm water $(73 \%)$.

\section{Distribution overlap}

The spatial predictors: latitude, longitude and depth, were significantly correlated with abundance for all 3 species, with depth being the best predictor (selected first into the models, Table 10). There was virtually no overlap in the predicted depth over which Hydrolagus bemisi and $H$. novaezealandiae were most abundant, and the abundance of $H$. bemisi declined as Harriotta raleighana increased (Fig. 4). $H$. raleighana and $H$. bemisi were more abundant at latitudes consistent with the southern flank of the Chatham Rise (ca. $44^{\circ} \mathrm{S}$ ) and rare on the northern flank (ca. $43^{\circ} \mathrm{S}$ ), whereas $H$. novaezealandiae was most abundant at latitudes aligned with the shallower water on the crest (ca. $43.5^{\circ} \mathrm{S}$; Fig. 4). H. raleighana was most abundant on the western Chatham Rise, $H$. bemisi on the western and central rise, and $H$. novaezealandiae on the eastern rise (Fig. 4). The median length of all 3 species decreased with increasing depth, with the strongest correlation between length and depth found in $H$. raleighana, and a negligible correlation found in $H$. novaezealandiae (Table 10, Fig. 5).

Table 10. Harriotta raleighana, Hydrolagus bemisi and Hydrolagus novaezealandiae. Results of the generalised additive regression models (GAM) for all 3 species, showing the selected predictors in each model (additional percentage variation explained in parentheses) and the predicted depth, latitude and longitude where the maximum catch rate occurred, and the results of the linear regression between median fish length $(\mathrm{DF}, \mathrm{cm})$ and tow depth $(D, \mathrm{~m})$ (all regressions were highly significant; $\mathrm{p}<0.001$ )

\begin{tabular}{|c|c|c|c|c|c|c|}
\hline \multirow{2}{*}{$\overline{\text { Model }}$ GAM } & \multirow[b]{2}{*}{ Depth (m) } & \multirow[b]{2}{*}{ Latitude } & \multirow[b]{2}{*}{ Longitude } & \multirow[b]{2}{*}{$\mathrm{n}$} & - Linear regression - & \multirow[b]{2}{*}{$\mathrm{r}^{2}$} \\
\hline & & & & & Model & \\
\hline \multicolumn{7}{|l|}{ Harriotta raleighana } \\
\hline Depth (31.0) + Latitude (6.5) + Longitude (4.4) & 991 & $44.0^{\circ} \mathrm{S}$ & $177.0^{\circ} \mathrm{E}$ & 224 & $\mathrm{DF}=-0.053 \times D+102.3$ & 0.32 \\
\hline \multicolumn{7}{|l|}{ Hydrolagus bemisi } \\
\hline Depth (60.3) + Longitude (5.3) + Latitude (2.3) & 621 & $43.8^{\circ} \mathrm{S}$ & $179.0^{\circ} \mathrm{E}$ & 1107 & $\mathrm{DF}=-0.027 \times D+83.1$ & 0.17 \\
\hline \multicolumn{7}{|l|}{ Hydrolagus novaezealandiae } \\
\hline Depth $(70.1)+$ Longitude $(0.7)+$ Latitude $(0.8)$ & 295 & $43.5^{\circ} \mathrm{S}$ & $177.7^{\circ} \mathrm{W}$ & 852 & $\mathrm{DF}=-0.009 \times D+60.3$ & 0.01 \\
\hline
\end{tabular}



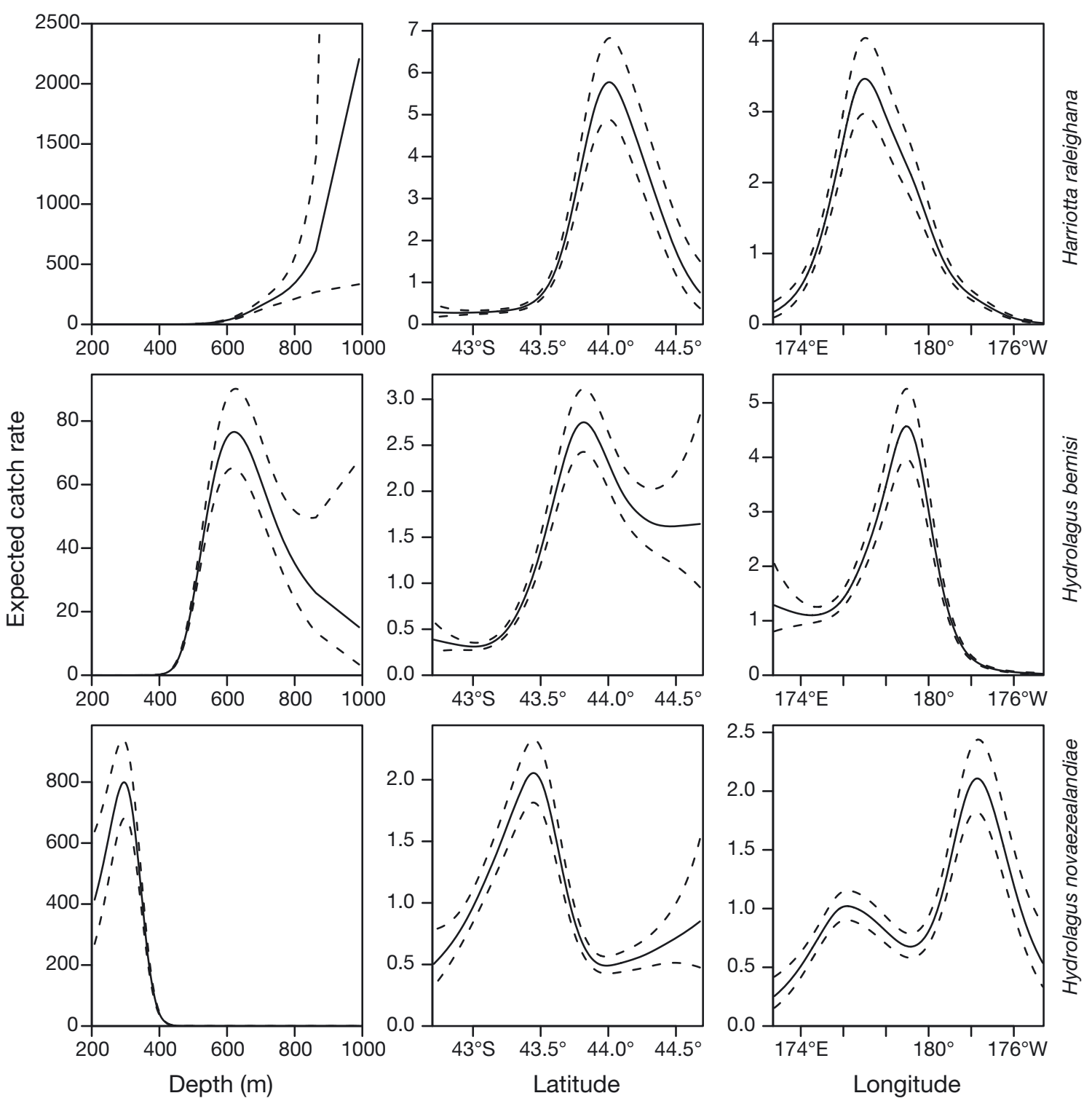

Fig. 4. Harriotta raleighana, Hydrolagus bemisi and Hydrolagus novaezealandiae. Predicted depth, latitude and longitude effects from a generalised additive regression model fitted to catch rate $\left(\mathrm{kg} \mathrm{km}^{-2}\right)$ for all 3 species. Broken lines indicate $1 \mathrm{SE}$

\section{DISCUSSION}

The diets of Harriotta raleighana, Hydrolagus bemisi and Hydrolagus novaezealandiae were characterised by benthic prey, consisting almost entirely of crustaceans, polychaetes, molluscs and echinoderms. In all 3 species, the digestive tract contents included a large proportion of fragmented and unidentifiable crustaceans and molluscs, which is consistent with these fishes crushing the prey between the tooth plates. Because of this mastication, the identification of prey in chimaeras was relatively difficult and time consuming and the examination of a chimaera digestive tract took an order of magnitude longer to complete than would a typical finfish stomach.

Benthic invertebrates are the predominant prey of all chimaeras studied to date, including Chimaera monstrosa (Macpherson 1980, Mauchline \& Gordon 1983, Bergstad et al. 2003, Moura et al. 2005), Hydrolagus africanus (Macpherson \& Roel 1987), H. colliei (Johnson \& Horton 1972) and H. mirabilis (Mauchline \& Gordon 1983). The diet of Harriotta raleighana on Chatham Rise was dominated by polychaetes, followed by gastropods, bivalves and amphipods, and was therefore similar to that reported for this species in the north Atlantic Ocean (Sedberry \& Musick 1978, 

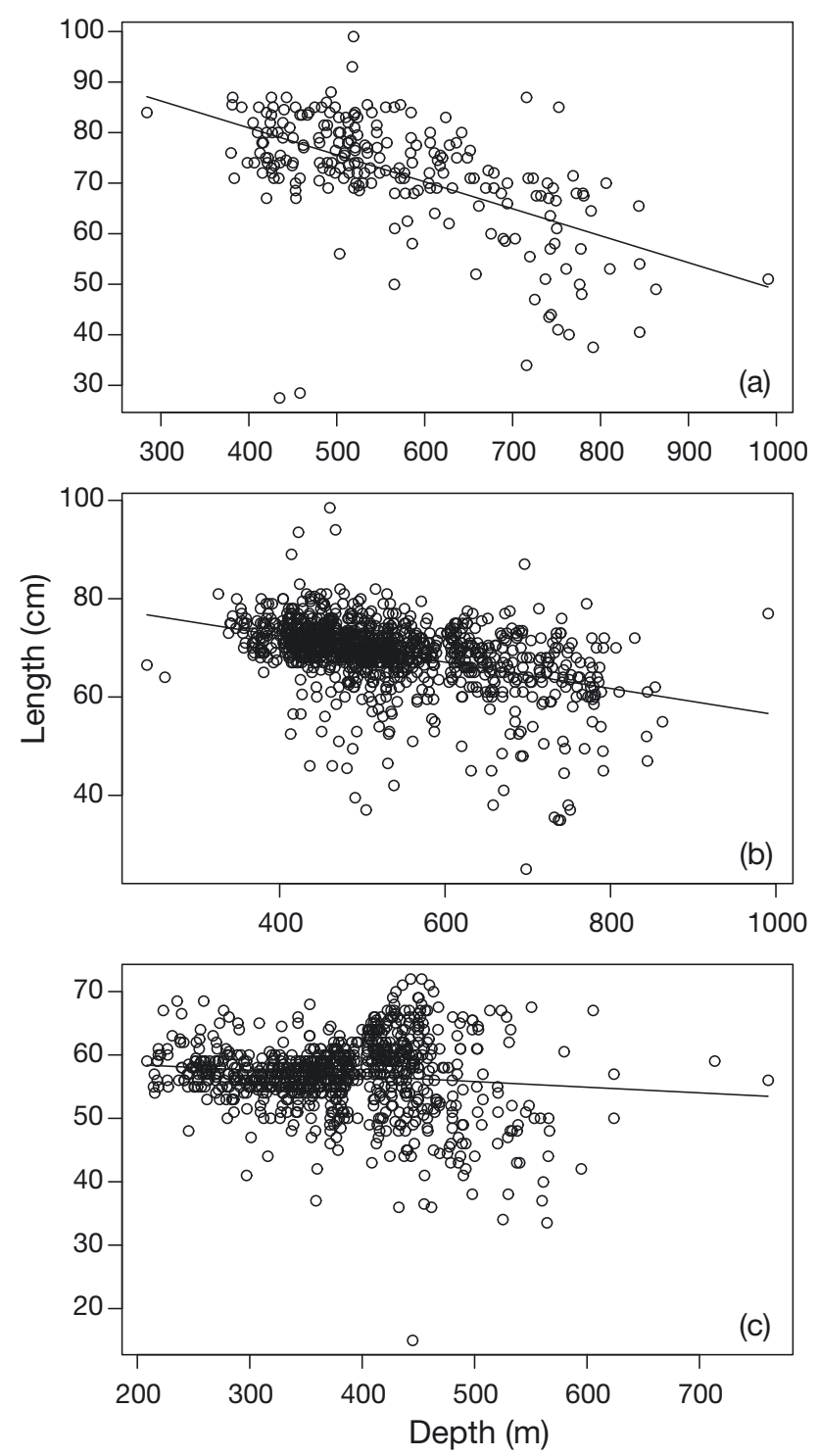

Fig. 5. Harriotta raleighana, Hydrolagus bemisi and Hydrolagus novaezealandiae. Median fish length (DF) plotted against depth in each tow for (a) H. raleighana, (b) H. bemisi and (c) H. novaezealandiae. Solid lines indicate fitted linear regressions

Mauchline \& Gordon 1983, González et al. 2007). Sedberry \& Musick (1978) concluded that H. raleighana may feed preferentially on infauna using its long snout as a sensory probe. The diet of Hydrolagus bemisi and Hydrolagus novaezealandiae, both of which lack the extended snout, was composed of a greater proportion of epifauna. The extension of the snout is most pronounced in Rhinochimaera pacifica, which is found most frequently in New Zealand waters at depths below $800 \mathrm{~m}$ (Last \& Stevens 2009); therefore, we hypothesise that the diet of $R$. pacifica could consist of a high proportion of infaunal prey. The diet of $R$. pacifica has not yet been studied.
The best predictor of diet variability was STF in Harriota raleighana and Hydrolagus novaezealandiae, and bottom temperature in Hydrolagus bemisi, indicating environmental variability was more important in determining diet than was fish size. The diet of Chimaera monstrosa varied with location in the north Atlantic Ocean (Mauchline \& Gordon 1983), and consisted predominantly of benthic crustaceans, echinoderms and polychaetes in the western Mediterranean Sea (Macpherson 1980), anemones, polychaetes, benthic crustaceans and echinoderms in the northeast Atlantic Ocean (Mauchline \& Gordon 1983, Moura et al. 2005), and polychaetes, bivalves, mysids and benthic crustaceans in the Skagerrak (Bergstad et al. 2003). Mauchline \& Gordon (1986) concluded that $C$. monstrosa may be selective upon specific prey or prey patches. Occasionally, large trawl catches $(>300 \mathrm{~kg}$ tow $^{-1}$ ) of $H$. novaezealandiae have been recorded, suggesting this species may form aggregations for feeding, or perhaps reproduction (Horn 1997). Small amounts of fish and squid have been found in the diet of C. monstrosa (Macpherson 1980, Mauchline \& Gordon 1983, Bello 1997, Moura et al. 2005), and Hydrolagus colliei (Johnson \& Horton 1972) and were also found in all 3 species studied here. Many of the fish remains we found were scales and fin rays, which may have been eaten in the net, but the remains also included digested flesh, bones and eyeballs, which indicates direct predation, or scavenging. Hydrolagus affinis has been observed visiting baits at depths of $2020 \mathrm{~m}$ in the north Atlantic Ocean (Priede et al. 1994), and several species have been caught on baited hooks, confirming scavenging behaviour, e.g. $H$. affinis (Forster 1964), Hydrolagus pallidus (Marques \& Porteiro 2000) and C. monstrosa (Clarke et al. 2005). Although the diet of chimaeras may be predominantly benthic fauna, scavenging behaviour suggests they retain a degree of opportunism.

Changes in diet with ontogeny were found in all 3 species studied here, with some common patterns: the diet of smaller fish included more polychaetes, small crustaceans (Amphipoda, Isopoda) and gastropods, and the diet of larger fish included more decapod crustaceans (Brachyura, Anomura). Broadly similar ontogenetic shifts in diet have been found for Chimaera monstrosa, with polychaetes and amphipods, and occasionally echinoderms or bivalves, being more important in smaller fish, and decapod crustaceans (largely Brachyura, Dendrobranchiata and Caridea) being more important in larger fish (Macpherson 1980, Mauchline \& Gordon 1983, Bergstad et al. 2003, Moura et al. 2005). Mauchline \& Gordon (1983) found the diet of small individuals of Hydrolagus mirabilis consisted predominantly of polychaetes and small crustaceans, with decapod crustaceans and echinoderms being 
important in larger individuals. The ontogenetic patterns in diet were broadly similar, even though the location and depth range inhabited by each species were different; this suggests the dietary preferences may be an obligate feature of ontogeny in chimaeras.

The greatest interspecific similarity in diet was between Hydrolagus bemisi at the shallower end of its range (in warmer water, mean depth $505 \mathrm{~m}$ ) and $H$. novaezealandiae at the deeper end of its range (crest of the Chatham Rise, depth range 350 to $499 \mathrm{~m}$ ). The 2 Hydrolagus species exhibited strong spatial separation in terms of depth (Horn 1997, Bull et al. 2001), as well as in latitude and longitude. The diet of $H$. bemisi in cooler and deeper water had greater similarity to Harriotta raleighana than to $H$. bemisi in warmer and shallower water. This indicates that distribution, and depth in particular, had a greater influence on diet than did species. $H$. bemisi and $H$. raleighana exhibited substantial separation in depth, but relatively little separation in latitude and longitude, with both species being more abundant on the south flank of the Chatham Rise, where temperatures are cooler and benthic flux is greater (Nodder et al. 2003).

Where Harriotta raleighana and Hydrolagus bemisi did overlap in depth, their trends in size with depth meant that larger $H$. raleighana and smaller $H$. bemisi co-occurred. Both have ontogenetic diet shifts such that food resource competition between them would be reduced. The trend of size at depth in $H$. bemisi and Hydrolagus novaezealandiae appears to be contrasting, as Horn (1997) reported smaller H. novaezealandiae were more abundant in water shallower than $200 \mathrm{~m}$; therefore, a common ontogenetic shift in diet in these species would not serve to reduce competition. However, the depth separation was more pronounced between $H$. bemisi and $H$. novaezealandiae, than between $H$. bemisi and $H$. raleighana.

There are at least 9 other chimaera species found in New Zealand waters. Species caught infrequently include Chimaera lignaria (Didier 2002), C. panthera (Didier 1998), Hydrolagus trolli and H. homomycteris (Last \& Stevens 2009), Harriotta haeckeli, the brown chimaera (Chimaera sp.), and the giant black ghost shark (Hydrolagus sp. D) (M. Francis pers. comm.). Rhinochimaera pacifica is a relatively common bycatch in deep-water trawls (>800 m), and differs from Harriotta raleighana as it is more frequently caught in deeper water $(>1200 \mathrm{~m})$ and to the north of the STF (Anderson et al. 1998), and has a much broader extended snout (Last \& Stevens 2009). The elephant fish Callorhynchus milii feeds on benthic molluscs and invertebrates (Gorman 1963) and is most abundant at depths less than $200 \mathrm{~m}$ (Francis 1998, Last \& Stevens 2009). The abundance of $R$. pacifica at depths $>1200 \mathrm{~m}$ and C. milii at depths $<200 \mathrm{~m}$ is consistent with a hypothesis of depth as a key determinant of species niches for chimaeras. Detailed information on spatial and depth distribution is lacking for the majority of chimaera species and other comparative studies of chimaera distribution seem to be absent.

Chimaeras overlap in distribution and share food resources with a number of teleost fishes: polychaetes are frequent in the diet of Caelorinchus bollonsi; benthic crustaceans, especially Munida spp., are frequent in the diets of Caelorinchus aspercephalus and Genypterus blacodes; crabs are frequent in the diets of Psuedophycis bachus and Helicolenus spp; but echinoderms and molluscs as prey seem to be largely exclusive to chimaeras (M. R. Dunn unpubl. data). The preference for echinoderms seems to place chimaeras in a unique trophic guild (Macpherson \& Roel 1987).

Whilst the diets of Harriotta raleighana, Hydrolagus bemisi and Hydrolagus novaezealandiae on Chatham Rise were all characterised by benthic prey, the diets varied with location, ontogeny and, to a lesser extent, species, with the greatest diet similarity occurring between the 2 Hydrolagus species. Competition for resources between the 3 species was greatly reduced by differing depth and spatial distributions and by similar ontogenetic depth and diet shifts. As a result, competition between chimaera species may be of minor importance in determining their population dynamics.

Acknowledgements. We thank Shane Ahyong, Owen Anderson, Amelia Connell, Graham Fenwick, Dennis Gordon, Niamh Kilgallen, Anne-Nina Loerz, Geoff Read, Kareen Schnabel and Darren Stevens (all NIWA). Thanks also go to Yves Cherel (Centre d'Etudes Biologiques de Chizé, France) and Oliver Coleman (Museum für Naturkunde, Berlin) for assistance in prey identification, and to 4 anonymous reviewers for constructive comments on the draft manuscript. This work was funded by the New Zealand Ministry of Fisheries Project ZBD2004-02 Objectives 1 and 3 and NIWA Project CF103089. We also thank the staff of the RV 'Tangaroa' for surveys and collection of the samples.

\section{LITERATURE CITED}

Alonso MK, Crespo AE, García AN, Pedraza NS, Mariotti AP, Mora JN (2002) Fishery and ontogenetic driven changes in the diet of the spiny dogfish, Squalus acanthias, in Patagonian waters, Argentina. Environ Biol Fishes 63:193-202

Anderson MJ, Gorley RN, Clarke KR (2008) PERMANOVA+ for PRIMER: guide to software and statistical methods. PRIMER-E, Plymouth

Anderson OF (2009) Fish discards and non-target fish catch in the New Zealand orange roughy trawl fishery: 1999-2000 to 2004-05. NZ Aquat Environ Biodivers Rep 39

Anderson OF, Bagley NW, Hurst RJ, Francis MP, Clark MR, McMillan PL (1998). Atlas of New Zealand fish and squid distributions from research bottom trawls. NIWA Tech Rep 42 National Institute of Water and Atmospheric Research (NIWA), Wellington 
Bax NJ (1998) The significance and prediction of predation in marine fisheries. ICES J Mar Sci 55:997-1030

Bello G (1997) Cephalopods from the stomach contents of demersal chondrichthyans caught in the Adriatic Sea. Vie Milieu 47:221-227

Bergstad OA, Wik ÅD, Hildre $\varnothing$ (2003) Predator-prey relationships and food sources of the Skagerrak deep-water fish assemblage. J Northwest Atl Fish Sci 31:165-180

Bradford-Grieve JM, Boyd PW, Chang FH, Chiswell S and others (1999) Pelagic ecosystem structure and functioning in the Subtropical Front region east of New Zealand in austral winter and spring 1993. J Plankton Res 21:405-428

Bray JR, Curtis JT (1957) An ordination of the upland forest communities of southern Wisconsin. Ecol Monogr 27: 325-349

Bull B, Livingston ME, Hurst R, Bagley N (2001) Upper-slope fish communities on the Chatham Rise, New Zealand, 1992-99. NZ J Mar Freshw Res 35:795-815

Clarke KR, Gorley RN (2006) PRIMER v6. PRIMER-E, Plymouth

Clarke KR, Warwick RM (2006) Change in marine communities: an approach to statistical analysis and interpretation, 2nd edn. PRIMER-E, Plymouth

Clarke MW, Borges L, Officier RA (2005) Comparisons of trawl and longline catches of deepwater elasmobranchs west and north of Ireland. J Northwest Atl Fish Sci 35: $429-442$

Cortés E (1997) A critical review of methods of studying fish feeding based on analysis of stomach contents: application to elasmobranch fishes. Can J Fish Aquat Sci 54:726-738

Cury PM, Shannon LJ, Roux JP, Daskalov GM, Jarre A, Moloney CL, Pauly D (2005) Trophodynamic indicators for an ecosystem approach to fisheries. ICES J Mar Sci 62: 430-442

Didier DA (1998) The leopard Chimaera, a new species of chimaeroid fish from New Zealand (Holocephali, Chimaeriformes, Chimaeridae). Ichthyol Res 45:281-289

Didier DA (2002) Two new species of chimaeroid fishes from the southwestern Pacific Ocean (Holocephali, Chimaeridae). Ichthyol Res 49:299-306

Dunn MR (2009) Feeding habits of the ommastrephid squid Nototodarus sloanii on the Chatham Rise, New Zealand. NZ J Mar Freshw Res 43:1103-1113

> Dunn MR, Rickard GJ, Sutton PJH, Doonan IJ (2009) Nursery grounds of the orange roughy around New Zealand. ICES J Mar Sci 66:871-885

Forster GR (1964) Line-fishing on the Continental Shelf. J Mar Biol Assoc UK 44:277-284

Francis MP (1998) New Zealand shark fisheries: development, size and management. Mar Freshw Res 49:579-591

Francis MP, Hurst RJ, McArdle BH, Bagley NW, Anderson OF (2002) New Zealand demersal fish assemblages. Environ Biol Fishes 65:215-234

Francis RC, Hixon MA, Clarke E, Murawski SA, Ralston S (2007) Ten commandments for ecosystem-based fisheries scientists. Fisheries 32:217-233

González C, Teruel J, López E, Paz X (2007) Feeding habits and biological features of deep-sea species of the northwest Atlantic: large-eye rabbitfish (Hydrolagus mirabilis), narrownose chimaera (Harriotta raleighana) and black dogfish (Centroscyllium fabricii). Northwest Atl Fish Org Sci Counc Meet Doc 07/63 Ser No. N5423

Gorman TBS (1963) Biological and economic aspects of elephant fish Callorhynchus milii Bory in Pegasus Bay and the Canterbury Bight. NZ Mar Dep Fish Tech Rep 8

Hastie T, Tibshirani R (1990). Generalized additive models. Chapman \& Hall, London
Heath RA (1985) A review of the physical oceanography of the seas around New Zealand-1982. NZ J Mar Freshw Res 19:79-124

Horn PL (1997) Biology and commercial landings and a stock assessment of ghost sharks (Hydrolagus spp.) in New Zealand waters. NZ Fish Assess Res Doc 97/3

> Hyslop EJ (1980) Stomach contents analysis: review of methods and their applications. J Fish Biol 17:411-429

Jaksic FM, Medel RG (1990) Objective recognition of guilds: testing for statistically significant species clusters. Oecologia 82:87-92

Johnson AG, Horton HF (1972) Length-weight relationship, food habits, parasites, and sex and age determination of the ratfish, Hydrolagus colliei (Lay and Bennett). Fish Bull 70:421-429

Kuha J (2004) AIC and BIC: comparisons of assumptions and performance. Sociol Methods Res 33:188-229

Last PR, Stevens JD (2009) Sharks and rays of Australia, 2nd edn. CSIRO publishing, Collingwood

> Leathwick JR, Elith J, Francis MP, Hastie T, Taylor P (2006) Variation in demersal fish species richness in the oceans surrounding New Zealand: an analysis using boosted regression trees. Mar Ecol Prog Ser 321:267-281

Liao H, Pierce CL, Larscheid JG (2001) Empirical assessment of indices of prey importance in diets of predacious fish. Trans Am Fish Soc 130:583-591

Macpherson E (1980) Food and feeding of Chimaera monstrosa, Linnaeus 1758, in the western Mediterranean. J Cons Int Explor Mer 39:26-29

Macpherson E, Roel BA (1987) Trophic relationships in the demersal fish community off Namibia. S Afr J Mar Sci 5: 585-596

Marques A, Porteiro F (2000) Hydrothermal vent mussel Bathymodiolus sp. (Mollusca: Mytilidae): diet item of Hydrolagus affinis (Pisces: Chimaeridae). Copeia 2000: 806-807

> Mauchline J, Gordon JDM (1983) Diets of the sharks and chimaeroids of the Rockall Trough, northeastern Atlantic Ocean. Mar Biol 75:269-278

> Mauchline J, Gordon JDM (1986) Foraging strategies of deep-sea fish. Mar Ecol Prog Ser 27:227-238

McClatchie S, Dunford A (2003) Estimated biomass of vertically migrating mesopelagic fish off New Zealand. DeepSea Res I 50:1263-1281

McKnight DG, Probert PK (1997) Epibenthic communities on the Chatham Rise, New Zealand. NZ J Mar Freshw Res 31:505-513

Ministry of Fisheries (2009) Stock status. Available at: fs.fish. govt.nz/Page.aspx?pk=16\&tk=114 (accessed 25 Nov 2009)

Moura T, Figueiredo I, Bordalo-Machado P, Gordo LS (2005) Feeding habits of Chimaera monstrosa L. (Chimaeridae) in relation to its ontogenetic development on the southern Portuguese continental slope. Mar Biol Res 1:118-126

Murphy RJ, Pinkerton MH, Richardson KM, Bradford-Grieve JM, Boyd PW (2001) Phytoplankton distributions around New Zealand derived from SeaWiFS remotely-sensed ocean colour data. NZ J Mar Freshw Res 35:343-362

Nodder SD, Pilditch CA, Probert PK, Hall JA (2003) Variability in benthic biomass and activity beneath the Subtropical Front, Chatham Rise, SW Pacific Ocean. Deep-Sea Res I 50:959-985

> Platell ME, Potter IC (2001) Partitioning of food resources amongst 18 abundant benthic carnivorous fish species in marine waters on the lower west coast of Australia. J Exp Mar Biol Ecol 261:31-54

Priede IG, Bagley PM, Smith A, Creasey S, Merrett NR (1994) Scavenging deep demersal fishes of the Porcupine 
Seabight, northeast Atlantic: observations by baited camera, trap and trawl. J Mar Biol Assoc UK 74:481-498

Probert PK, Grove SL, McKnight DG, Read GB (1996) Polychaete distribution on the Chatham Rise, Southwest Pacific. Int Rev Gesamten Hydrobiol 81:577-588

Pulliam HR (2000) On the relationship between niche and distribution. Ecol Lett 3:349-361

Robertson DA, Roberts PE, Wilson JB (1978) Mesopelagic faunal transition across the Subtropical Convergence east of New Zealand. NZ J Mar Freshw Res 12:295-312

Sedberry GR, Musick JA (1978) Feeding strategies of some demersal fishes of the continental slope and rise off the mid-Atlantic coast of the USA. Mar Biol 44:357-375

Editorial responsibility: Paul Snelgrove,

St. John's, Canada
Stevens DW, O'Driscoll RL, Horn PL (2009) Trawl survey of hoki and middle depth species on the Chatham Rise, January 2008 (TAN0801). NZ Fish Assess Rep 2009/18

Sutton P (2001) Detailed structure of the subtropical front over Chatham Rise, east of New Zealand. J Geophys Res 106(C12):31045-31056

Tirasin EM, Jørgensen T (1999) An evaluation of the precision of diet description. Mar Ecol Prog Ser 182:243-252

Uddstrom MJ, Oien NA (1999) On the use of high-resolution satellite data to describe the spatial and temporal variability of sea surface temperatures in the New Zealand region. J Geophys Res 104(C9):20729-20751

Submitted: December 4, 2009; Accepted: March 12, 2010

Proofs received from author(s): May 11, 2010 